\title{
Public Art in Urban Regeneration. Piotrkowska street. Pride of a city: Łódź
}

\author{
Antoni Remesar \\ Polis research Centre- CRIT Research Group, Universitat de Barcelona \\ aremesar@gmail.com
}

\begin{abstract}
Piotrkowska street is the centre of $Ł o d z$. A continuous axis of more than $4 \mathrm{~km}$ that runs through the territory from north to south. A long shopping street divided into two clearly differentiated sections. The first from Wolności Square to Centrum Piotrkowska (approx. $2 \mathrm{~km}$ and cross section between 16 and $24 \mathrm{~m}$ ). The second from Centrum Piotrkowska to Niepodległości square (approx $2.2 \mathrm{Km}$ and cross section between 25 and $30 \mathrm{~m}$ ). From the very beginning, the street was the central axis around which the city was developing, and its development spontaneously gave the present shape to its centre.
\end{abstract}

In the second section of the street, trams circulate and, despite having some important heritage facilities such as the "White Factory", the former headquarters of the Karol Scheibler industries and today the headquarters of the Central Textile Museum, it does not have the recognition that the first stretch.

The first section of the street is the one that appears in all tourist guides, is the commercial and cultural heart of the city, a favourite meeting place for Łódź residents and tourists. Here festivals, concerts, sporting events, parties and fairs take place.

Piotrkowska street still is flagship of the urban regeneration processes in Łódź, along with Manufaktura, and the mega urban regeneration project Nowe Centrum, with the city's new central station, the EC1 cultural complex, and the expansion of the University of Łódź campus. Territory in which the Expo 2022 was to be developed, which will finally be held in Buenos Aires.

Piotrkowska's urban regeneration process clearly incorporates a public art strategy. The particularity of this strategy lies in its contents, specifically those who propose, manifest or emphasize the "pride of the city".

Keywords: Piotrkowska street; Lodz; Urban Regeneration; Public Art 


\section{Resumen}

La calle Piotrkowska es el centro de Łodz. Un eje continuo de más de $4 \mathrm{~km}$ que atraviesa el territorio de norte a sur. Una larga calle comercial dividida en dos secciones claramente diferenciadas. El primero desde la plaza Wolności hasta Centrum Piotrkowska (aprox. 2 km y sección transversal entre 16 y 24 m). El segundo desde Centrum Piotrkowska hasta la plaza Niepodległości (aprox. 2,2 km y sección transversal entre 25 y $30 \mathrm{~m}$ ). Desde el principio, la calle fue el eje central alrededor del cual se desarrolló la ciudad, y su desarrollo dio espontáneamente la forma actual a su centro.

En la segunda sección de la calle, circulan los tranvías y, a pesar de tener algunas instalaciones patrimoniales importantes como la "Fábrica Blanca", la antigua sede de las industrias de Karol Scheibler y hoy sede del Museo Textil Central, no tiene el reconocimiento que el primer tramo.

La primera sección de la calle es la que aparece en todas las guías turísticas, es el corazón comercial y cultural de la ciudad, un lugar de encuentro favorito para los residentes y turistas de Łódź. Aquí se realizan festivales, conciertos, eventos deportivos, fiestas y ferias.

La calle Piotrkowska sigue siendo el buque insignia de los procesos de regeneración urbana en Łódź, junto con Manufaktura, y el mega proyecto de regeneración urbana Nowe Centrum, con la nueva estación central de la ciudad, el complejo cultural EC1 y la expansión del campus de la Universidad de Łódź. Territorio en el que debía desarrollarse la Expo 2022 que finalmente se celebrará en Buenos Aires.

El proceso de regeneración urbana de Piotrkowska incorpora claramente una estrategia de arte público. La particularidad de esta estrategia radica en su contenido, específicamente aquellos que proponen, manifiestan o enfatizan el "orgullo de la ciudad".

Palabras Ilave: calle Piotrkowska; Lodz; Regeneración urbana; Arte publico

\section{Resum}

El carrer Piotrkowska és el centre de Łodz. Un eix continu de més de $4 \mathrm{~km}$ que recorre el territori de nord a sud. Un Ilarg carrer comercial dividit en dues seccions clarament diferenciades. El primer des de la plaça Wolności fins a Centrum Piotrkowska (aproximadament $2 \mathrm{~km}$ i secció entre 16 i $24 \mathrm{~m}$ ). El segon, des de Centrum Piotrkowska fins a la plaça Niepodległości (aproximadament 2,2 km i secció entre 25 i $30 \mathrm{~m}$ ). Des del principi, el carrer va ser l'eix central al voltant del qual es desenvolupava la ciutat i el seu desenvolupament va donar de forma espontània la forma actual al seu centre.

Al segon tram del carrer circulen els tramvies $i$, tot i tenir algunes instal.lacions patrimonials importants com la "Fàbrica Blanca", antiga seu de les indústries de Karol Scheibler i avui seu del Museu Central del Tèxtil, no té el reconeixement que té el primer tram.

El primer tram del carrer és el que apareix a totes les guies turístiques, és el cor comercial i cultural de la ciutat, lloc de trobada favorit dels residents i turistes de tódź. Aquí hi tenen lloc festivals, concerts, esdeveniments esportius, festes i fires.

El carrer Piotrkowska segueix sent insígnia dels processos de regeneració urbana de Łódź, juntament amb Manufaktura, i el mega projecte de regeneració urbana Nowe Centrum, amb la nova estació central de la ciutat, el complex cultural EC1 i l'expansió del campus de la Universitat de Łódź. Territori en el que hauria de desenvolupar-se l'Expo 2022 que finalment es celebrarà a Buenos Aires.

El procés de regeneració urbana de Piotrkowska incorpora clarament una estratègia d’art públic. La particularitat d'aquesta estratègia rau en els seus continguts, concretament en aquells que proposen, manifesten o posen l'èmfasi en el "orgull de la ciutat".

Paraules clau: carrer Piotrkowska; Lodz; Regeneració Urbana; Art públic 


\section{Piotrkowska street, axis of Łódź 's urban growth}

As a monolith reminds us, that initially, Piotrkowska Street was a route tract leading from Łódź to Piotrków Trybunalski in the south and to Zgierz and Łęczyca in the north. The classic city centre with a market, shops and the amenities of public life focused around it never took shape in $Ł o ́ d z^{1}$. Piotrkowska Street has assumed this role with time.

"The spatial structure of an industrial city was shaped in the form of belts of settlement that became nodes initiating the later filling-in of urban space with built-up areas. The development was regular, dispersed and monotonous, and the structure (still readily discernible) ensured that for decades Łódź was known for its elongate North-South shape, as well as a unique centre running along what is today Piotrkowska Street for as many as 4 km, plus a checkerboard pattern of intersecting streets".(Wójcik, M, Tobiasz-Lis, P, \& Dmochowska-Dudek 2018)

In 1821, Rajmund Rembieliński - president of the Mazowieckie Voivodship Commission - began activities aimed at regulating the factories settlement. This settlement was called the "New Town" and it was located south of the "old" Łódź. On the settlement plan, a route line was marked, along which there were blocks and standard single-plots, $17.5-21 \mathrm{~m}$ wide, assigned to weaving craftsmen. The plot allocation depended on the type of production declared. The period of "craftsmen" quickly ended when factories were established on the outskirts of the New Town that took over craft production. After 1863 and the liquidation of local government bodies, Łódźs urban planning ceased and the city began to expand spontaneously.

The Piotrków Route in the "new" Łódź, since then called Piotrkowska Street, was until 1865 the main communication link between Łódź and Piotrków Trybunalski, which involved horse-drawn passenger and freight traffic using large wagons and stagecoaches. At the same time, the tract played the role of an internal road connecting individual workshops of weaving craftsmen of various specialties, listing their semi-finished products, and focusing the internal life of the emerging industrial city. Therefore, Piotrkowska Street was a kind of internal courtyard and market square for the great "Łódź manufacture", which was the whole New Town. This function is explained by the fact that a classic city centre with a centrally located market and co-expanding commercial and public institutions was never formed in Łódź, and its tasks were taken over by ul. Piotrkow.

Originally (around 1815) the name "Piotrkowska Street" was used for the northern part of the road connecting the then Old Market Square and the New Market Square, i.e. today's ul. Nowomiejska, the initial section of ul. Zgierska and pl. Kościelny - while the southern section (today's ul. Piotrkowska) had no name. Soon, however, the name "Piotrkowska Street" was given to the entire section of the Piotrków Route, which ran in the newly founded craft settlement, i.e. in the New Town. This name was given by the mayor of the Old Town, Antoni Czarnkowski, and builder of the Łęczyca region, Dürring. In 1823, tablets with this name were erected, and five years later the name was confirmed in a government letter and applied to the settlement plan.

1.- Piotrkowska Street and the centre of the city, would correspond to the form of urban growth that Solà-Morales calls "suburban growth"(Solà-Morales, Manuel 1993) 
In the second half of the nineteenth century large modern enterprises began to emerge, including plants owned by Karol Scheibler, Israel Poznanski and Ludwik Grohman. At the end of the century, Łódź became the largest industrial centre in Poland. Piotrkowska Street was definitely developed. In 1887, the Grand Hotel was opened, designed by Hilary Majewski (originally a wool and cotton factory owned by Ludwik Meyer). In 1888, the Victoria Theatre was inaugurated, later transformed into cinema "Poland". The large industrialists also developed real estate projects. Some linked to the construction of palaces for their own residence, others boosting apartment buildings and offices.

Piotrkowska Street was a place of prestige, the plots were much more expensive here than in the outskirts. This resulted in the large density of villas and palaces for businessmen in the city, buildings between party walls and public buildings in various architectural styles, such as the NeoRenacentist Palace of the factory owner, Juliusz Heinzel; the printer's property and founder of the first newspaper in Łódź, Johann Petersilge; The palace of one of the largest industrial companies in Łódź, Karol Scheibler or the palace of the industrialist Juliusz Kindermann.

Many pioneering actions in the history of the city are related to Piotrkowska Street. It was here when the first brick house was built in 1835. In 1869, the Łódź Society of Gas installed the gas lighting for the first time. In 1876 the first stone pavement was placed, called cobblestones along the entire length of the street, and the 1898 the first electric tram stepped on this street.

With the German occupation in 1939 the street and the city lost their name. The street was renamed Adolf Hitler and Łódź to become Litzmannstadt. On 11 April 1940, Łódź disappeared from all maps. The city of Litzmannstadt appeared in its place, named in honour of General Karl Litzmann, a Prussian general, the hero of the Battle of Lodz (First World War). They disappeared from the map as so did the thousands of Jews confined in Litzmannstadt's ghetto. It was the second largest ghetto after Warsaw. It was originally intended as a point of concentration of the Hebrew population, eventually becoming an important industrial centre, providing supplies for the German war machinery. Due to its extraordinary productivity, the ghetto managed to survive until August 1944, when the remaining population was deported to Auschwitz, being the last ghetto in Poland. It was closed on 19 January 1945 with the arrival of the Soviet Army.

From 1945 the street suffered a gradual degradation, although, in 1950, the trams and routes of the tramway move to Tadeusza Kościuszk Avenue, which runs parallel to Piotrkowska, with the intention of relieve it.

Until the 1970s the historic buildings of the street were not considered monuments worthy of being preserved by the authorities of the time. Several of them were demolished and instead office buildings and shopping centres were built. In the 1980s some decorative elements were removed from the facades, dangerous to passers-by, although the restoration of some buildings had already begun.

Since 1990 the character of the street starts to change. This year, Marek Janiak, architect and member 
of the art group Lodz Kaliska, proposed the idea of creating the "Foundation of Ulica Piotrkowska". The aim of the Foundation was to revitalize the street and transform it into a pedestrian zone. A first section was paved with colourful cobblestones and was equipped with modern street lamps and other elements of urban furniture. This intervention was harshly criticized by art curators and historians because it did not adapt to the general street atmosphere. Between 1993 and 1997, the following sections of the street were renovated and pedestrianized in a northerly direction towards Wolności [Freedom] square. They were paved with black cobblestones that mimicked the old pavement and equipped with more elements of urban furniture. However, each part had a different pavement and urban furniture of different style, which was also criticized.

The definitive reconversion of the street begins with the approval of "Development Strategy of Piotrkowska Street in Łódź for the years 2009-2020". The Development Strategy of Piotrkowska Street was created because the Łódź residents clearly stated that Piotrkowska needed it, Łódź needed it.

The inhabitants of Piotrkowska themselves, its users and supporters, together with the city authorities, through public consultations, which were held in the form of meetings of the Piotrkowska Staff appointed by the Mayor of the City, agreed its shape and tasks.

The effects of the Piotrkowska Staff were adopted in the form of a social contract under the name 'Piotrkowska Contract'. Parallel to the work of Piotrkowska Staff, marketing research was carried out on the street in order to objectify the current situation and accurately define the development policy for Piotrkowska. As the introduction of the document points out

"Dear Lodzians, Dear Lodzians, nothing stands in the way of adding Pietryna to the pantheon of the most famous streets in the world. Because what is Piotrkowska worse than Parisian Champs Elysées, Barcelona's La Rambla, London's Oxford Street, or New York's Broadway? It is in no way inferior to them, what is better, because ours. Restoring the glow of Piotrkowska Street is our duty, which we cannot only achieve, but must fulfil" (Rady Miejskiej w Łodzi 2009).

Piotrkowska is the centre of the Łódź metropolis. Lodzians work here, live, study and relax. Therefore, everything should be done to restore the former splendour of the street and at the same time breathe the spirit of new times into its space. It should be clearly stated that Piotrkowska Street, does not compete with other existing or planned complexes that perform similar functions in Łódź. Łódź is a big city, and its inhabitants need places of diverse nature that will focus the city's cultural, entertainment and business life.

It should also be noted that from January 1, 2012, Piotrkowska was subject to thorough modernization and reconstruction. The adopted solution assumes that the floor surface along the entire width of Piotrkowska is one plane (without curbs). Thus, there is no intention in which part of the road lane would be separated as a roadway. In addition, at least in two locations, i.e. at the intersection of Piotrkowska with Roosevelt street motion separators will be introduced in the form of movable posts. 


\section{Łódź Urban Regeneration Strategies}

The strategy for Piotrkowska represents a turning point in the local development of Łódź. The political regime change in Poland in 1990 coincides with a deep economic crisis that has a major impact on the economic base of the city with the practical disappearance of the textile industry that for 150 years was the basis of its urban development. Łódź is facing, as before with other cities such as Barcelona (Bohigas, Oriol 1985; Borja, Jordi 1988; Borja, Jordi (ed) 1995, a deep reconstruction process in which specific "small-scale" (El Haddad, Marie 2017) interventions must be combined with large projects for comprehensive regeneration (Hernando, Mateo; Remesar Aguilar, Nemo A. 2011; Remesar Aguilar, Nemo 2016, Remesar, Antoni 2019) . As in other European cities, Poland's entry into the European Union (2004) will allow for scale-up operations thanks to the receipt of European financial funds.)

Łódź it is one of the fastest shrinking cities in Europe due to the economic crisis in the 1990s following the systemic transformation in Poland and in other CEE countries.

The reasons for the shrinking of the city cannot be attributed to the economic and demographic situation alone but also to the degradation of the central part of the city and low quality of housing available in the nineteenth century buildings in the area. The overall image of Łódź as a city in crisis, which prevailed for many years after the collapse of its industry, resulted in low investment attractiveness compared to other large cities in Poland. (Kazimierczak J. \& Kosmowski P. 2017)

Population data express very well the "decline" of the city. In 1990 Łódź had about 900.00 inhabitants. Thirty years later it did not reach 700,000 and the City Council forecast for 2050 places the city's inhabitants below 500,000.

While Barcelona, for its reconstruction, opted for a dialectical "centre-periphery" strategy that gave rise to the so-called "Barcelona Model"(Borja, Jordi (ed) 1995; Capel, Horacio 2005; Monclús, Fco. Javier 2003; Montaner, J.M.- Alvarez, F- Muxí, Z (ED) 2011; Remesar, Antoni 2013), Łódź opts for a strategy of "reconversion of its centre". In 2005 the city buys the old power plant known as EC1; in 2006 it reached an agreement with PKP (Polish Railway) to reconvert the Fabryczna central station, very close to EC1, with the motto "Station Down, Culture Up"; in 2007 The Nowe Centrum Łodzi program is initially proposed, complemented by the 2012 Integrated Development Strategy for Lodz 2020+ (ZLPR), which will be complemented in 2013 with the Łódź 2020+ Spatial Development Strategy and Culture Development Policy 2020+ for the City of Łódź (MPZP). Esta estrategia facilita que Łódź presente su candidatura, 2015, para celebrar en 2022 una Exposición Internacional con la temática "City Re-Invented". This strategy facilitates Łódź to present its bid, 2015, to host in 2022 an International Exhibition with the theme "City Re-Invented". Finally, the Bureau International des Expositions (BIE) opts to choose the city of Buenos Aires to host the exhibition with the theme "Creative industries in Digital Convergence". 


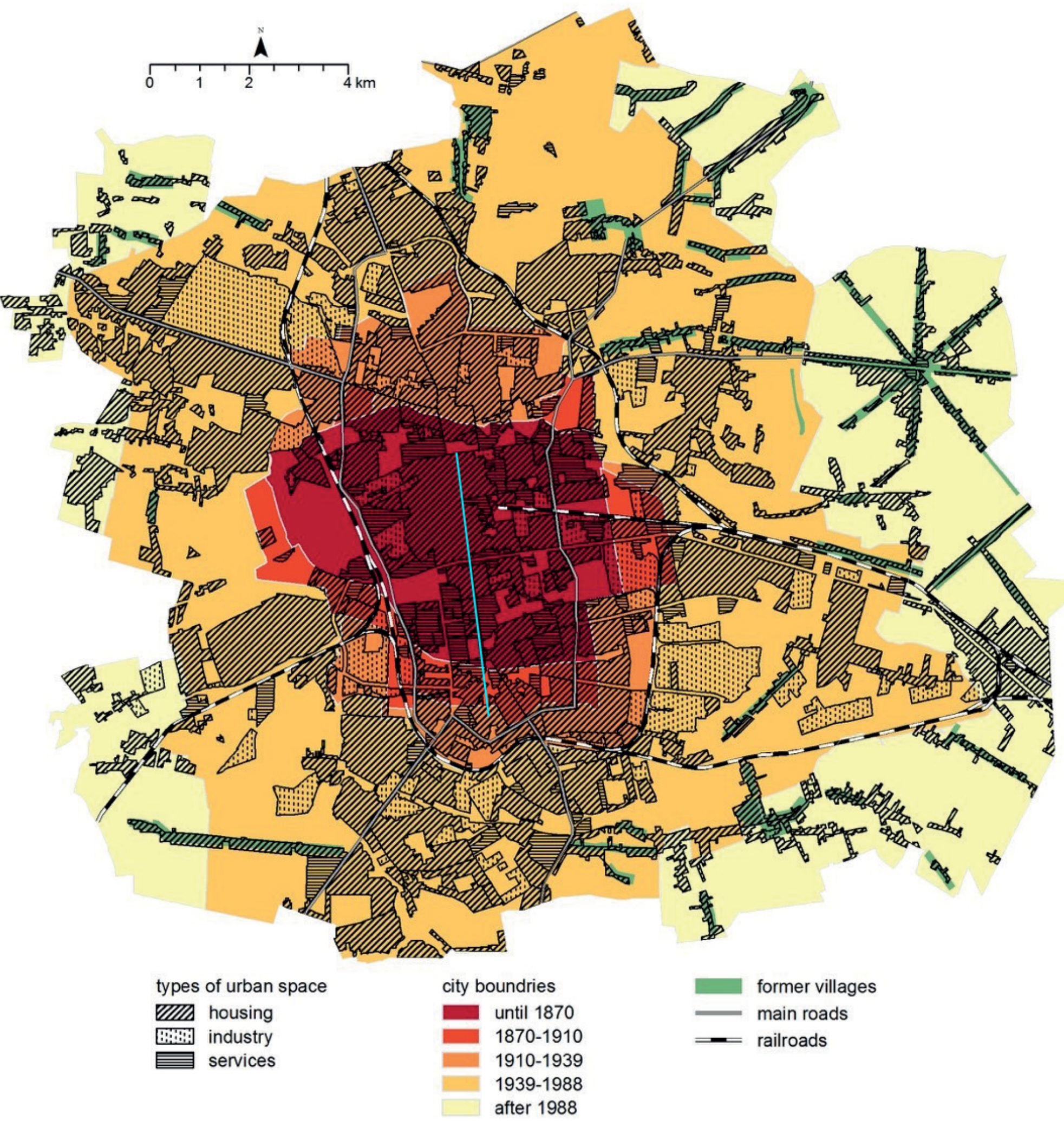

The territorial development of Łódź in context of contemporary functional structure

Source: Wójcik, M, Tobiasz-Lis, P, \& Dmochowska-Dudek 2018 


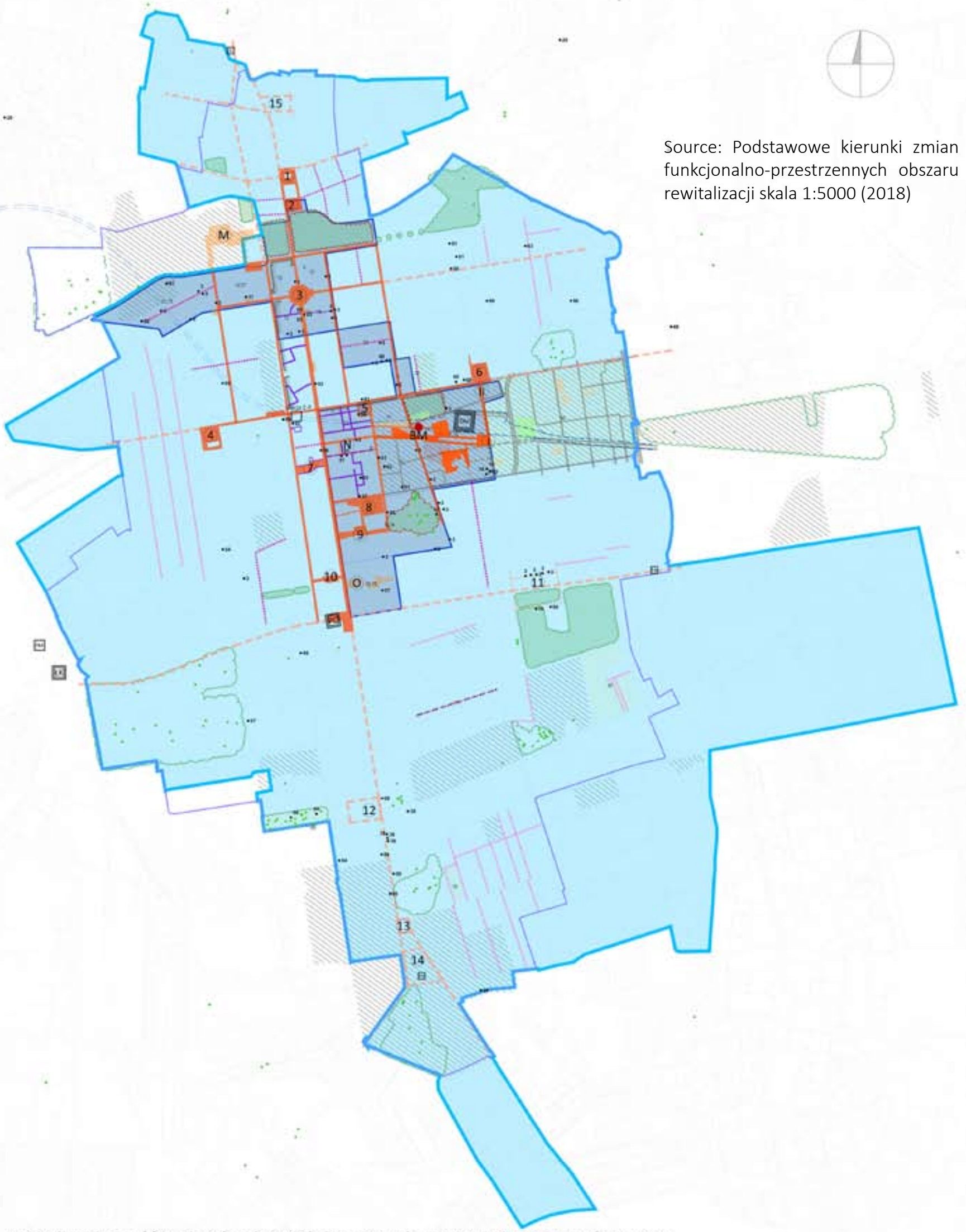

Basic directions of functional and spatial changes in the regeneration area, scale 1: 5000

Podstawowe kierunki zmian funkcjonalno-przestrzennych obszaru rewitalizacji skala 1:5000

LEGENDA:

OEsear: AREAS:

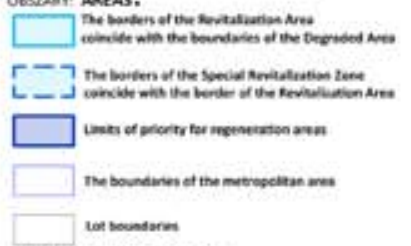

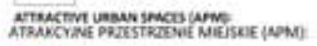

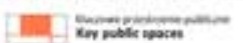

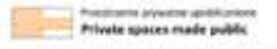

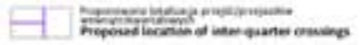

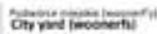

If

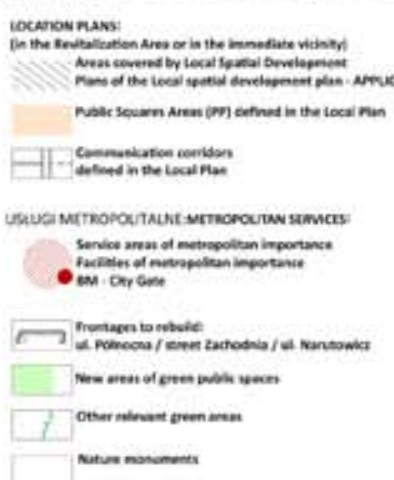

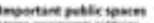

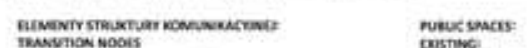

cosnive:

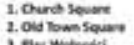

1. Fis Whineks

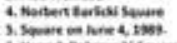

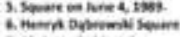

7. W. Nene hatwitis

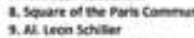

3.M. leon schilit

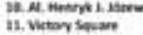

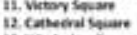

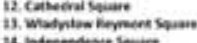

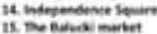

moverni:

Irobio seven:

wernutr areat

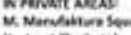

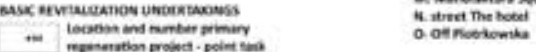

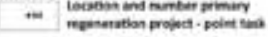

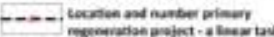

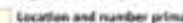




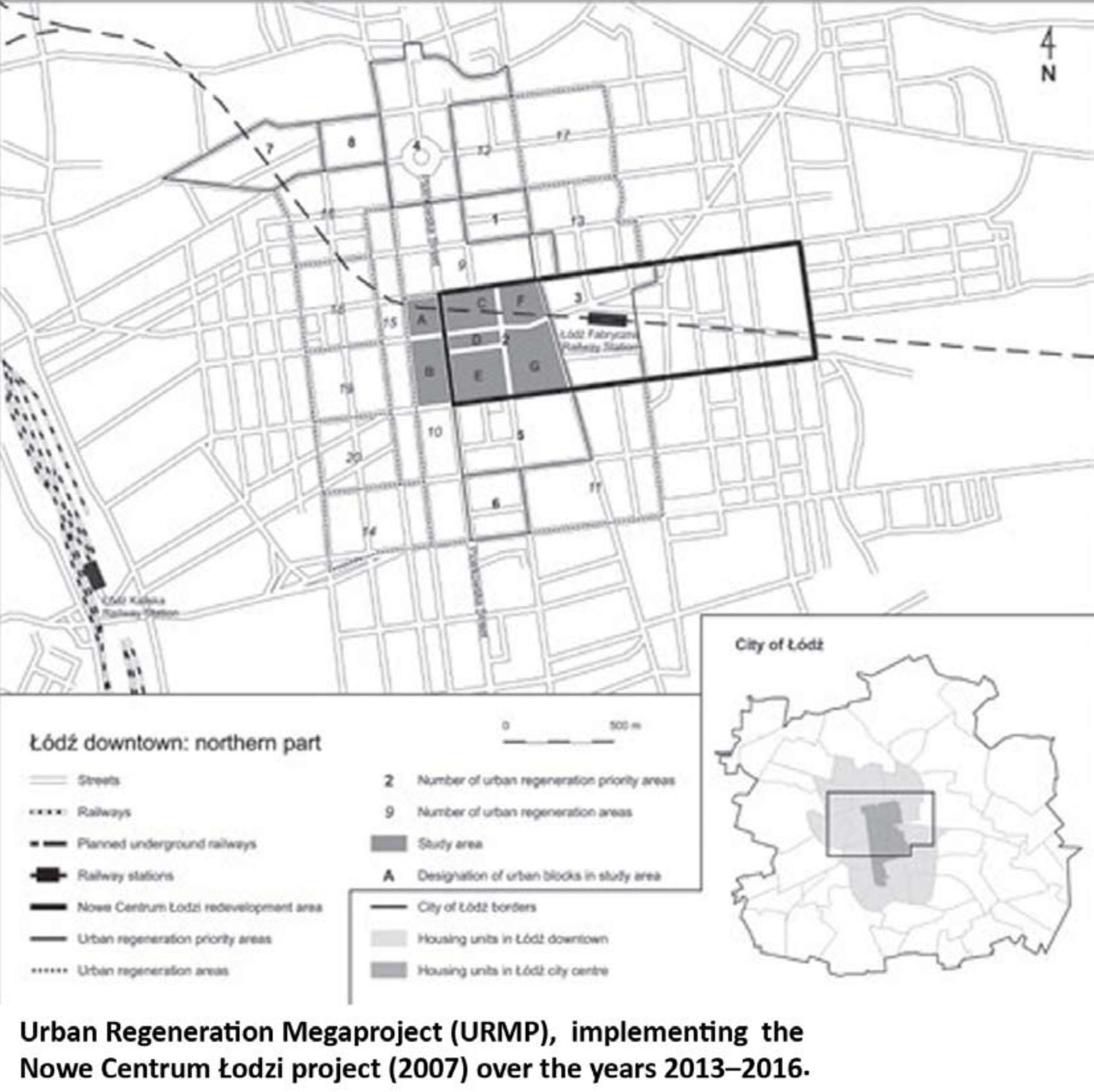

\section{Source: Kazimierczak J. \& Kosmowski P. (2017)}

the city of Łódź.

As a result, the project will contribute to increase the level of integration and coordination of public policies by providing computer tools to supervise and analyse the indicators and execution activities of the project carried out in the revitalization area of the city of Łódź.

The idea of this set of projects articulated in the regeneration strategy aim to unlock the potential of the centre of Łódź for its inhabitants correcting the deficit of social cohesion, improving the image of the area, recovering the economy and overcoming the residential crisis. 
Analysing this strategy, it is surprising the importance of aspects of "urban aesthetics" (GralinskaToborek, Agnieszka- Kazimierska-Jerzyk, Wioletta 2014; Remesar, Antoni 2016; Kazimierska-Jerzyk, W. 2015; Kazimierska-Jerzyk, W. 2019). Changes in the aesthetics of space seem crucial, with green cuts and planting street vegetation and small vegetation enclaves (for example, pocket parks), which can change radically (enrich or impoverish) urban space. Also regarding the empowerment of heritage aspects (conservation and restoration, information) and symbolic (public art programs) and monuments.

\section{Urban Regeneration Strategy for Piotrkowska Street}

The Development Strategy of Piotrkowska Street in tódź for the years 20092020 was built using the environmental method. It was created because the Łódź residents clearly stated that Piotrkowska needed it, Łódź needed it. The inhabitants of Piotrkowska themselves, its users and supporters, together with the city authorities, through public consultations, which were held in the form of meetings of the Piotrkowska Staff appointed by the Mayor of the City, agreed its shape and tasks. Staff Piotrkowska effects work have been adopted in the form of social contract entitled "Contract for Piotrowska". Parallel to the works of Piotrkowska Staff, marketing research was carried out on the street in order to objectify the current situation and accurately determine the development policy for Piotrkowska. The Piotrkowska Street Development Strategy in Łódź for the years 2009-2020 is a document that reflects both the tasks specified in the "Piotrkowska Contract" and the conclusions of the study, while maintaining the form of a strategic document. (Rady Miejskiej $w$ Łodzi 2009)

Strategic planning, despite the criticism it has received (Arantes, C-Vainer, C- Maricato, E 2002), is a common tool in city planning since the early 1980s. The plan sets a goal to achieve: Improving the street in its spatial, social and economic spheres, since Piotrkowska is a showcase of the metropolitan Łódź, a European street with important economic, cultural, tourist and entertainment functions, a friendly place for residents and guests. It is a long-term plan, based on promotion and urban marketing, aimed at generating a positive image emphasizing the character of the central place of Łódź. The main strategic objectives are:

\begin{tabular}{l|l|l|l} 
Sphere & spatial & social & economic \\
\hline \hline Objective & $\begin{array}{l}\text { Spatial and } \\
\text { infrastructural } \\
\text { order of } \\
\text { Piotrkowska street }\end{array}$ & $\begin{array}{l}\text { Quality of life and } \\
\text { social capital of } \\
\text { Piotrkowska Street }\end{array}$ & $\begin{array}{l}\text { Economic attractiveness of } \\
\text { Piotrkowska street }\end{array}$ \\
\hline
\end{tabular}

The strategy as a whole is summarized in the following tables.

The results of this strategy are evident when visiting the street. The preservation of architectural heritage and urban design has been significantly improved and a clear desire to "monumentalize" the street through public art is evident. 
I. Improving the quality of Piotrkowska street space

\section{Spatial and infrastructural order of Piotrkowska Street}

II. Improving transport accessibility on Piotrkowska Street
1. Development of the principles of space management at Piotrkowska Street

2. Construction and modernization of public and semi-public spaces

\section{Revitalization of the quarters adjacent to} Piotrkowska Street

\section{Improving the quality of urban greenery}

1.1. Freparationand adoptian of a local spatial develooment plan for Piotrkowska street and adjacent quarters 1.2. The introsuction of a ban on the location of buildings that do not meet the requirements of metropolitan buildings ans the removal of building anbitraniness

13. Developing rules for the functioning of advertising media and store windowson Piotriowika

1.4. Preparation of cleanliness rezulations for St, and its strict enforcement

21. Rehublitation and thematization of the space of passages: biewsk, Schiller and Rubinstein and construction of new passages at Piotrikowska 2.2. Development of public space development concept in front of SDH Centrall

23. Equioping the street space with new elementsemphasizing the character of the street, elements of street furniture - "street furniture"

24. Reolacement or change of location as well as liquidation of facilities such as beothi, wiosk

2.5. Inatallation of street fountains

26. Fiegair of building facades, fates and development of side walls that do not require major renovation

3.1. Development of conservation and spatial guidelines for buildings in the quarters adjacent to Piocriowaka Stree 3.2. Development and implementabon of the quarter development contept: Zachodnia, Nowomiejika, Ogrodows, Lepionów, Fac Wolnoso 3.3. Revitalication of the "southern area" under the PROREVITA program

3.4. Revitalitution of the "morthem eres" under the PRoheVIT A proegram

3.5. "Plac Woinodi - salon toder" - implementation of the ad apted concengt of transforming the stbum

3.6. Development of legat tools enabling the develcpent? and protection of Fotrkowsia Street as a place with special historical, aesthetic and culturalvalues

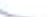

1. Infrastructure development and reorganization of road traffic

4.1. Renovation of the Staromiejsti Park as a space connecting Manufaktura and Wolnoidi square 4.2. Improvine the condition of areenery on Piotrkowika street

\section{Development and modernization of infrastructure for the needs of walking and cycling}

3. Expansion and modernization of the infrastructure network
11. Development and implementation of the concept of phase-out of car traffic on Fictrhowska street from PI. Wolnoici to Al. Mickiewiet / Pitsudiks

12. Designation of the location and construction of multi-storevear parks in the immediate winty of Piotrkowska Street

2.1. Construction of technical infrastructure for oycling on Piotrkowika Street 2.2. launch of the municipal bicyde rental systen

2.3. Construction of the City Intormation Systemi

24. Construction of an attractive pedestrian connection Piotriowska wath ECl and todif Fabrycan Ralway Station and Mantaktura

3.1. Construction of an intrastructurechmel with feplactment of the surface 3.2. Staged replacement of the heating and energy network and othes measures to reduce emiscions

\section{MAP OF ACTORS}

\section{Real Estate Administrati ons, private owners}

\section{Central Commercial} Cooperative

The company "Ruch S.A."

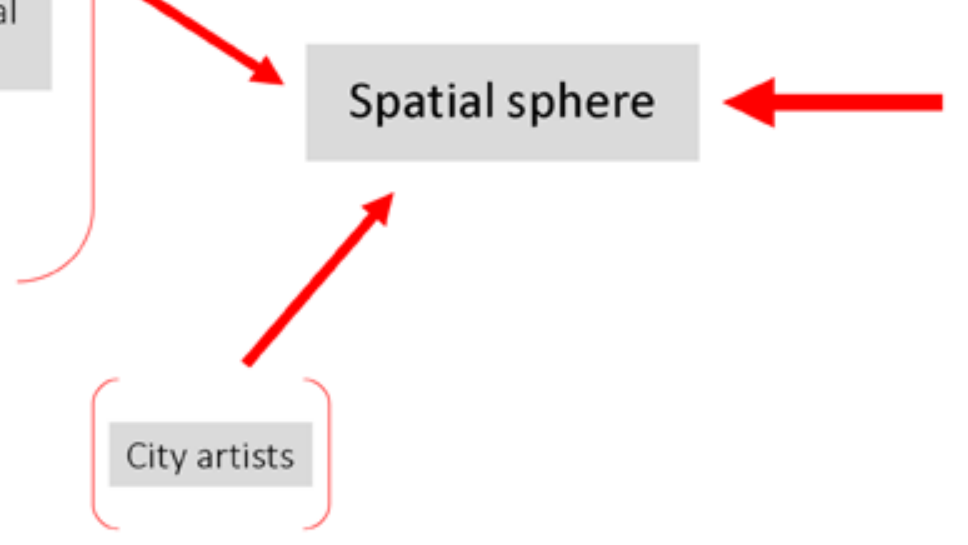

\section{Municipal Urban Projects Unit}

Department of Spatial Planning and Monument Protection

Road and Transport Authority

\section{ZOP}

Municipal Police

Department of Water and Sewage

Department of Environmental

Protection and Agriculture,

Commission of gardens

Delegation of the Lodz downtown district 
III. Improving public order

Quality of life and social capital of Piotrkowska Street

IV. Improving the attractiveness of social space
1. Ensuring the safety of Piotrkowska street users

\section{Elimination of social} problems

\section{Improving communication security}

4. Improvement of lighting in Piotrkowska Street

1. Activation and building relationships among the inhabitants of Piotrkowska Street

2. Building the identity of the place

\section{Improving the quality of housing stock on Piotrkowska}

4. Improvement of lighting in Piotrkowska Street
III Developmert of a riskmap on Piotrikowika street

12. Piotrikouska'ssecurity ares - "Piotrkowska's Guests"

1.3. "Municipal Guard fer you, for tod $z^{2}$ - populatiation of secure phone numbers: 986 and 112

1.4. Construction of mobile video monitoring

1.5. Construction of the Event Reportinz Svstem (alert points)

21. Preparation of a backyard partnership buildingerogram (toulding sexialcapital)

22. Improvement of information about free tolets on Piotrkowika Street and construction of public toilets - "Fraerant Backyards" campaign 2.3. Preparation and restrictive enforcement of eood manners in the implementation of the "Frazrant tlackyards" action

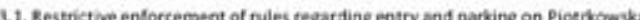

3.2. Developing policy principles for improving the puality, safery and aesthetics of rickshaws.

4.1. Illumination of arcades, gates and courtyard:

4.2. Extension of canopr lehting and modernization of dumination lighting

1.1. Popularization and promotion of joint neighborhood nitiatives

1.2. "Potrikowska Salons" - popularization of good behavior leading to the improvement of the condition of Fictrikowiala Street and sctivation of iss inhabieanti
MAP OF ACTORS

\section{Social sphere}

Municipal Urban Projects Unit

Department of Spatial Planning and Monument Protection

Road and Transport Authority

Municipal Police

ZOP

Department of Environmental Protection and Agriculture,

Department of Property Management

Tourism and International Cooperation Office

Municipal Center of Geodetic and Cartographic Documentation

Delegation of the Lodz downtown district 
V. Enhancing central and metropolitan functions in Piotrowska

\section{Economic} attractiveness of Piotrkowska street

VI. Improving tourist attractiveness
1. Location of institutions with center-forming functions

2. Elimination of social problems

3. Strengthening the academic character of Piotrkowska Street
1. Developing tourism product Piotrowska Street

\section{Improving tourist} infrastructure
1.1. Preparation of support prozrans for the location of center-forming inatitutions

1.2. The location of institutions emphasizing the character of "Film todz" on Potrikowska

1.3. Implementation of active policy regarding the location of institutions with center -forming functions

2.1. Preparation of a backyard partnership building program (building social capital)

2.2. Improvement of information about free toilets on Piotrkowska Street and construction of public tollets - "Fragrant Bechyards" cumpaign

2.3. Preparation and restrictive enforcement of good manners in the implementation of the "Frazrant Backyards" action

3.1. Cooperation with universities in the area of location of academic building at Piotriowska 3.2. Organization of events by universities in tódi at Piotrkowska
3. Strengthening the attractiveness and multiculturalism of Piotrkowska Street
1. Building a virtual Piotrkowska model with the possibility of a virtul walk

12. Making the walking function of Piotrkowka Street more attractive

1.3. Extending the activity of the Tourist information Center in the field of integration of cultural, tourist and entertuinment informaticn

1.4. Preparation of a series of guides on the hotel, gastronomy and entertainment cffer of Piotrkowska and the center

2.1. Preparation of tourist routes around Piotrkowlk:

2.2. Development and implementation of the "Tourist Card" system

2.3. Preparation and orzanization of the program of permanent walks with a guide around Piotrkowska

2.4. Construction of a viewing platform at Piotrkowika Street

2.5. Preparation of places for the organization of mass events on Piotrikowika

3.1. Preparation of the multicultural trail on Piotrkowika Street

3.2. Development of ewent designs related to multiculturalism and filmmaking of $t$ bdi taking place on Piotrkowska Street and their promotion

3.3. Preparation of a schedule of events related to multiculturalismand filmmaking in todt' organized on Potrkowska Street

MAP OF ACTORS

Municipal Urban Projects Unit

Department of Spatial Planning and Monument Protection

\section{ZOP}

Department of Property

Management

Tourism and International

Cooperation Office

Tourist Information Centre

Department of Land Surveying and Inventory

Municipal Center of Geodetic and Cartographic Documentation

Delegation of the Lodz downtown district

\section{Department of Education}

Department of Strategy and Analysis

Department of Buildings and Premises

Office for Enterprise Development and Workplaces (Team for video) 


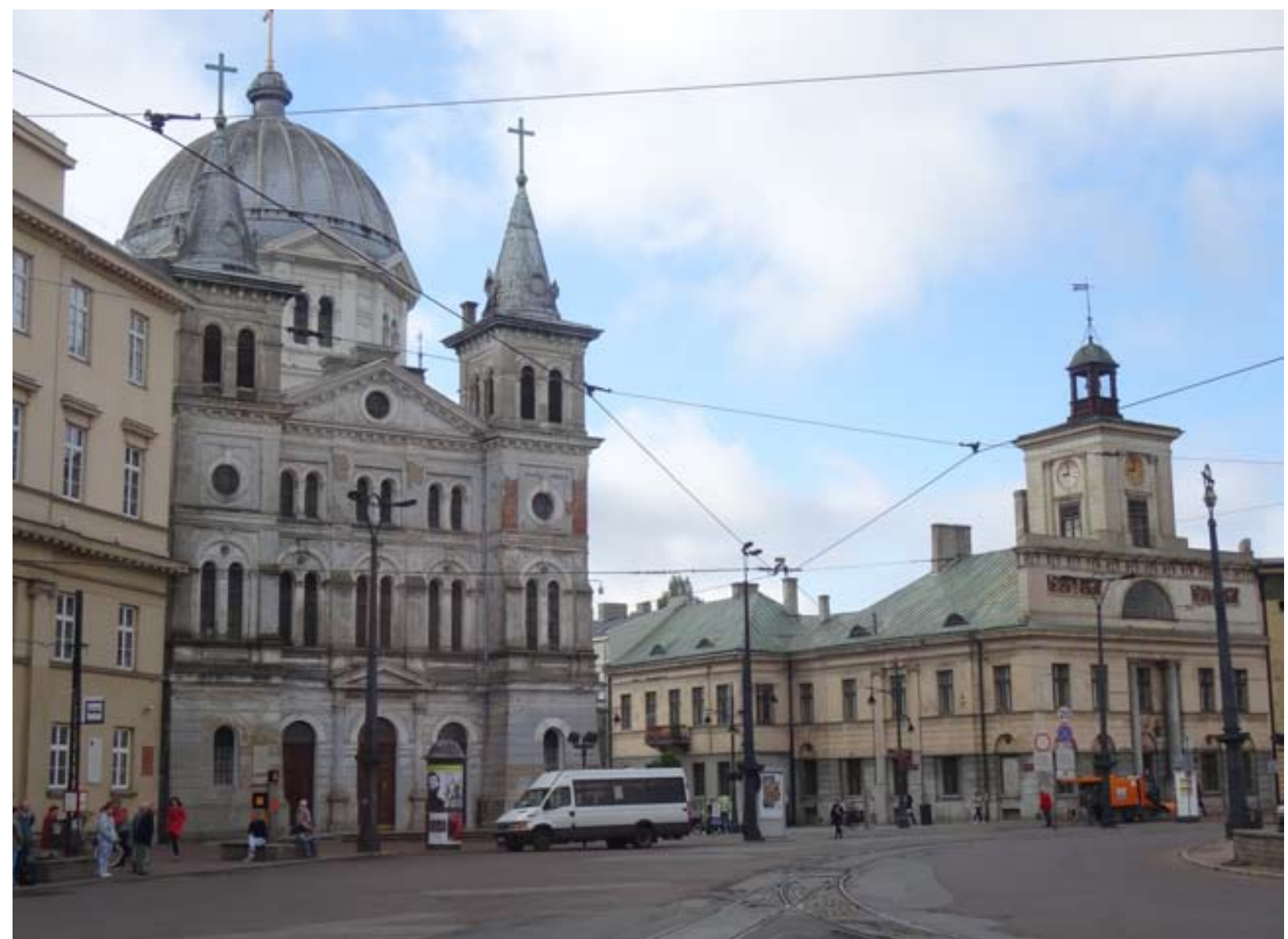

Evangelical church dedicated to the Holy Trinity.

It was built in the years 1826-1828. Its original shape was similar to the magistrate Łódź building on the opposite side. The author of the project was Bonifacy Witkowski. In 1889-1892 the temple was completely re-built according to the design of Otto Gehlig and Hilary Majewski

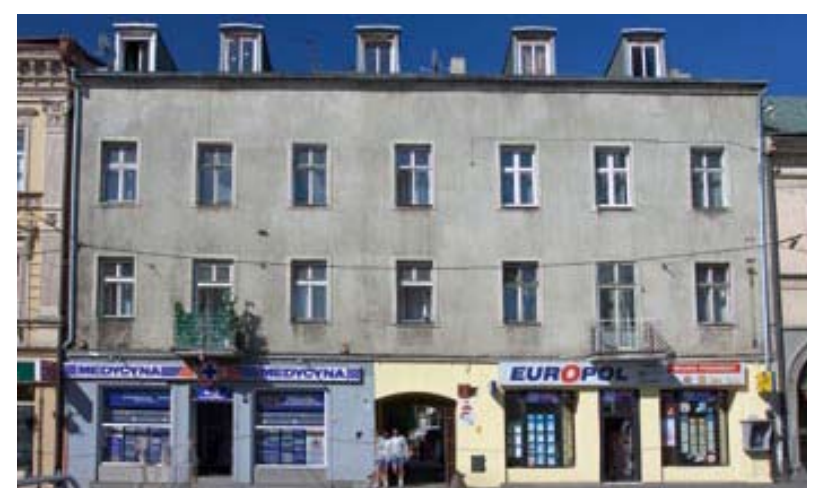

The former Hotel Polski
Łódź Town Hall

One of the first stone buildings in Łódź, erected in 1827 according to the design of Bonifacy Witkowski. It is the most valuable and oldest monument of classical architecture in Łódź. Stands out a clock given by the entrepreneur Ozorków - Schlösser installed in 1834 by watchmaker Michał Strangos

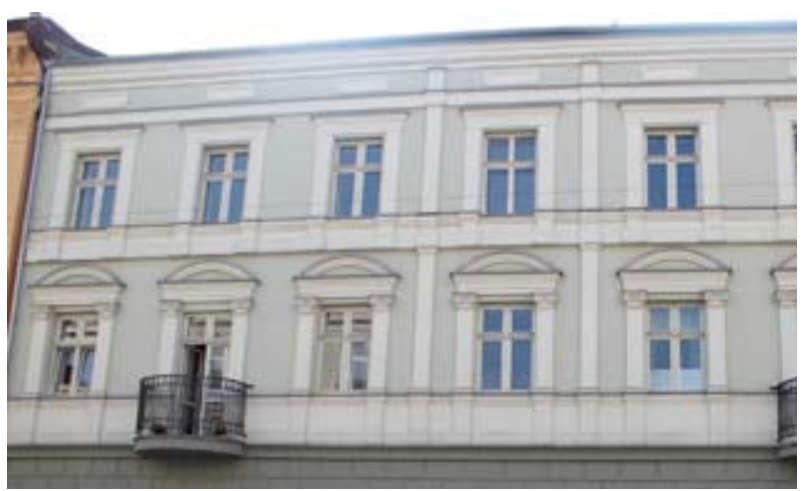

Built in 1835. Originally it was a simple two storey inn designed by Jan Karol Mertsching - the architect of łęczycki region (C) (Machlański, Piotr 2010) (C) http://baedekerlodz.blogspot.com/ 2018 


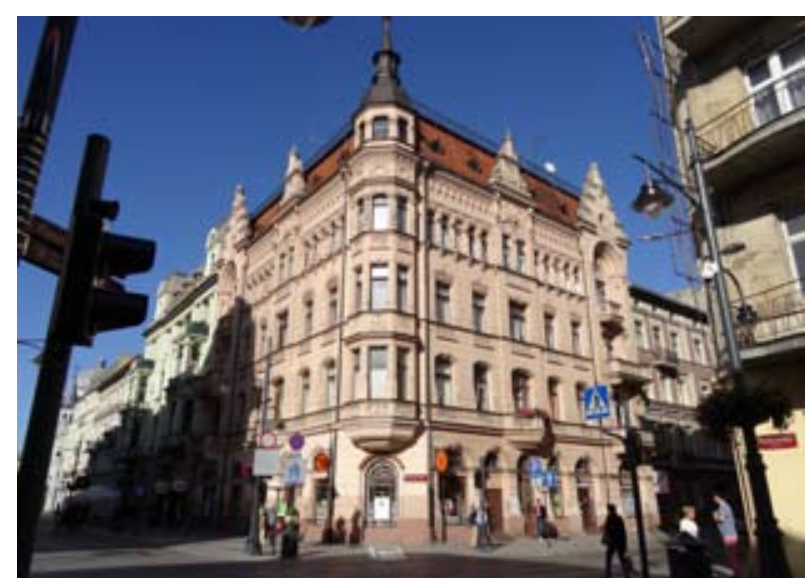

Sendrowicz's Tenement House

Built in 1898 for Izrael Sendrowicz. It was designed by a Łódź architect, Dawid Lande

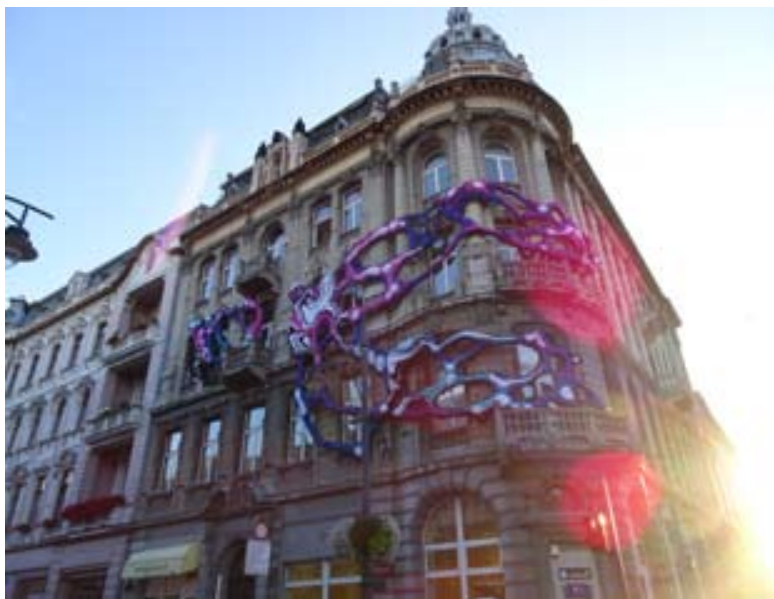

The former Landau Banking House

Designed by a popular Łódź architect Gustaw LandauGutenteger, 1902

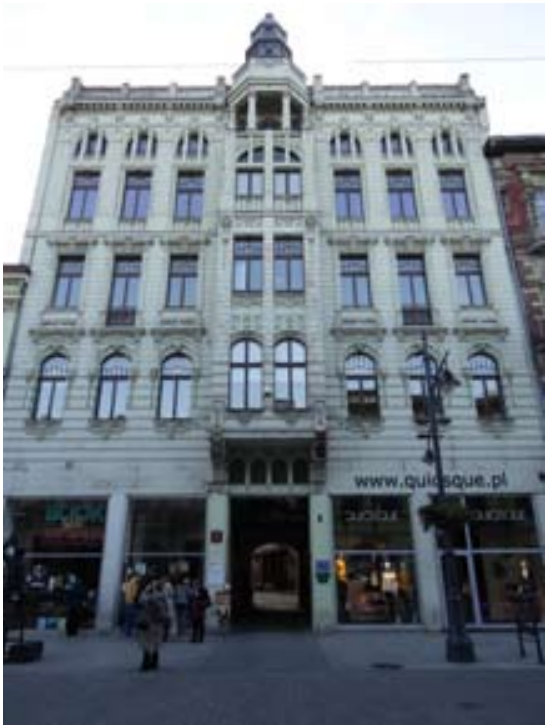

Szmulowicz's Tenement House

It was designed by Gustaw Landau-Gutenteger and erected between 1903-1904 for Jakub Szmulowicz

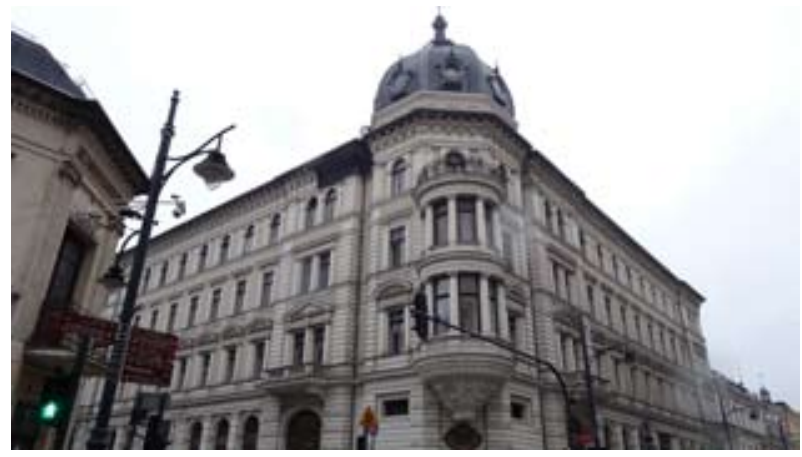

Scheibler's Tenement House

Built in 1879-1881 for Karol Scheibler and designed by Hilary Majewski

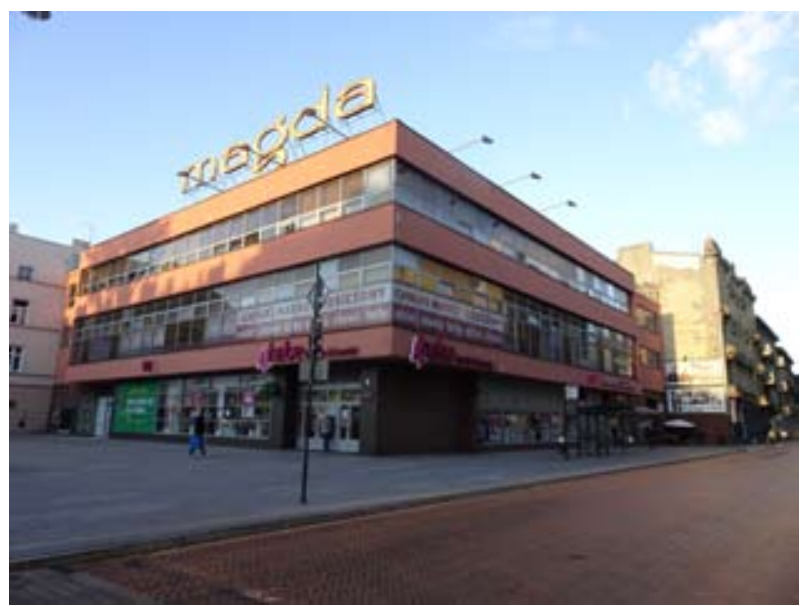

"Magda"

Department store well-known in the communist period.

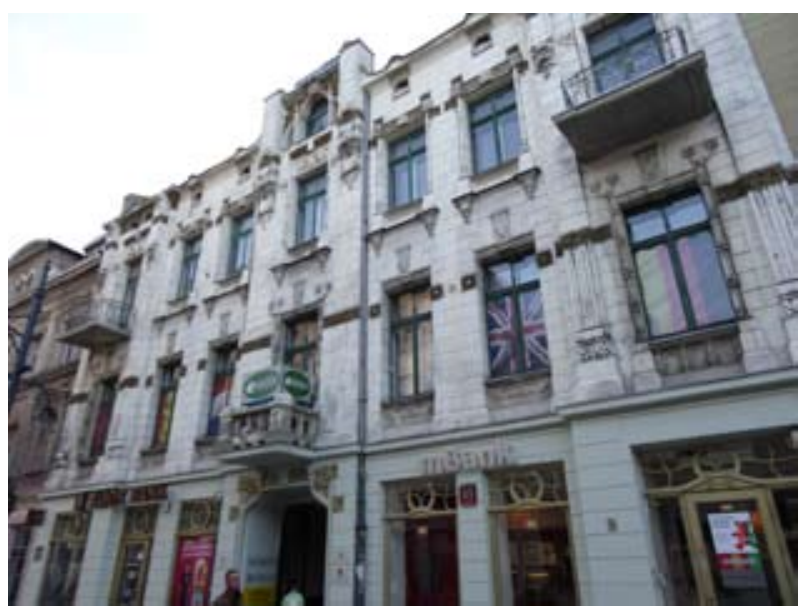

Kohn's Tenement House

It was designed by Gustaw Landau-Gutenteger and erected between 1901-1902 


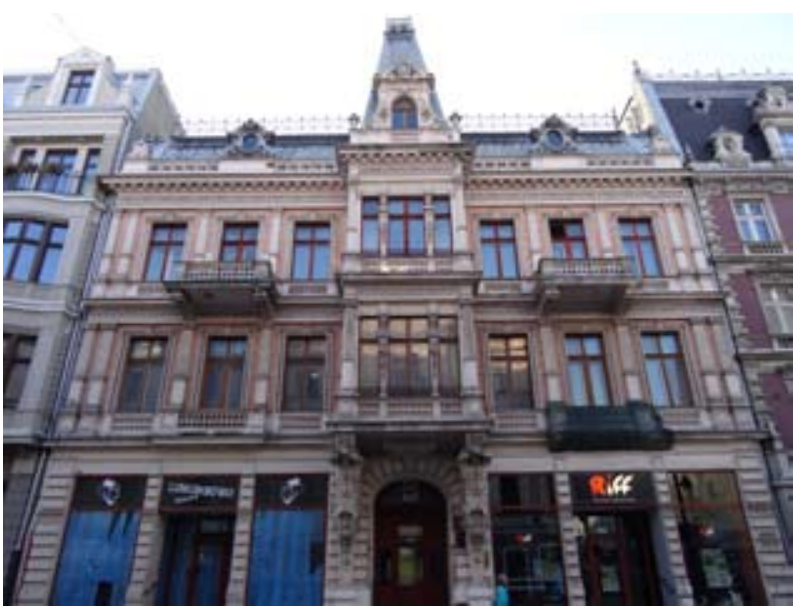

Konstadt's Tenement House

1885

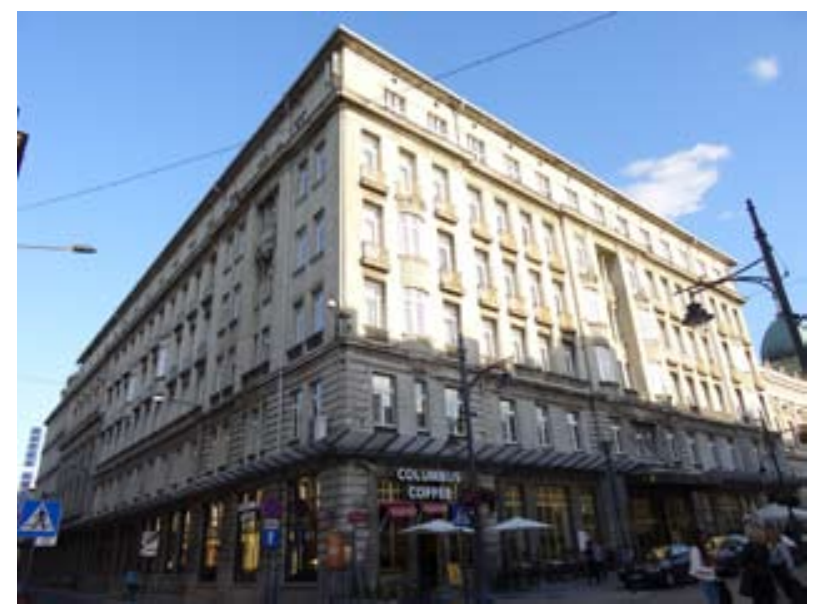

\section{Grand Hotel}

The building previously served as Ludwik Meyer's factory, it was re-adapted as a hotel in 1912-1913 according to a project by Hilary Majewski and Dawid Lande.

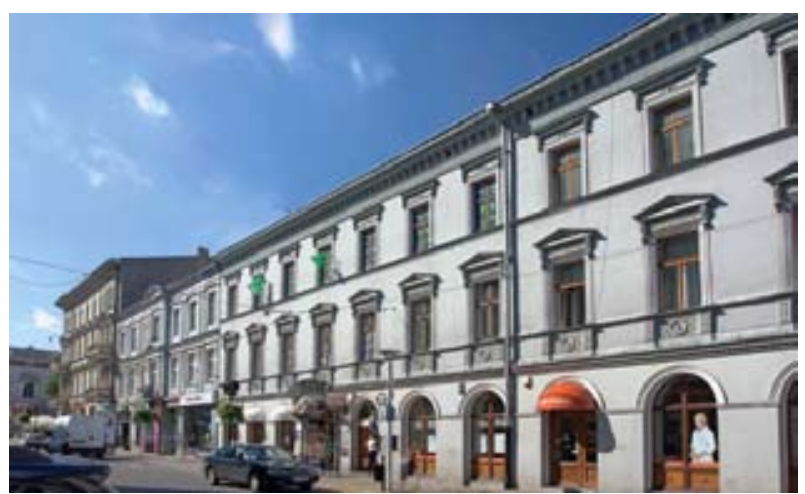

The former "Victoria" Hotel and "Victoria" Theatre

1876 C (Machlański, Piotr 2010)

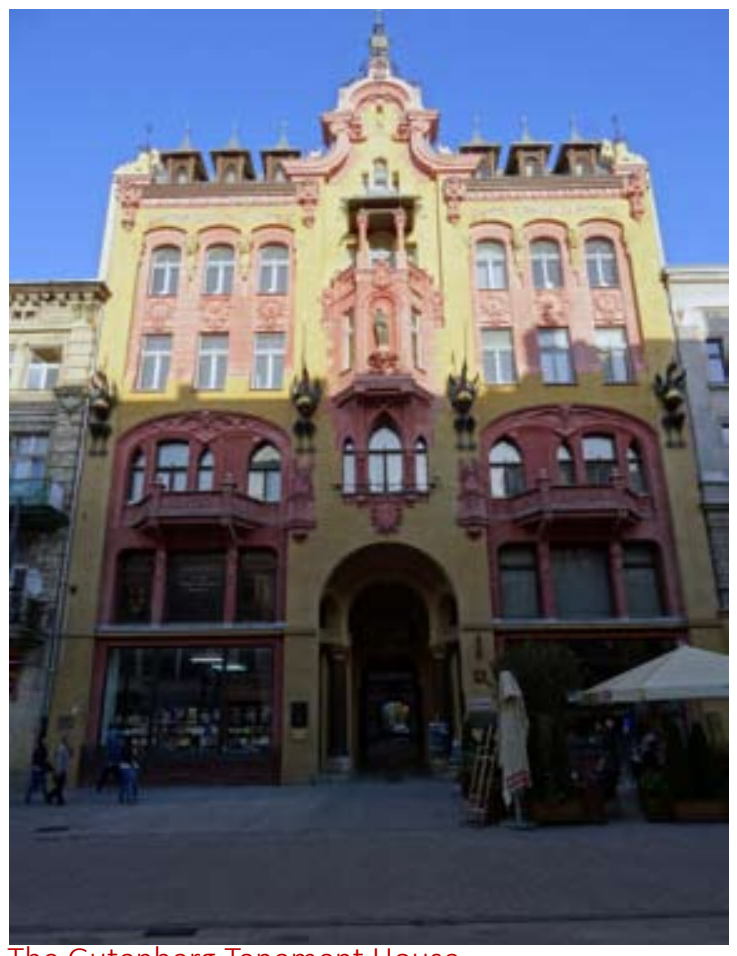

The Gutenberg Tenement House

The building was named after a sculpture of Johannes Gutenberg, the inventor of movable type printing, placed in a niche in its bay. The house replaced the former home of Filip Lisner. It was constructed in 1896 and 1897 for Jan Petersilge - lithographer, printer and issuer of the first newspaper in Łódź: „Lodzer Anzeiger Advertisements from Łódź". 


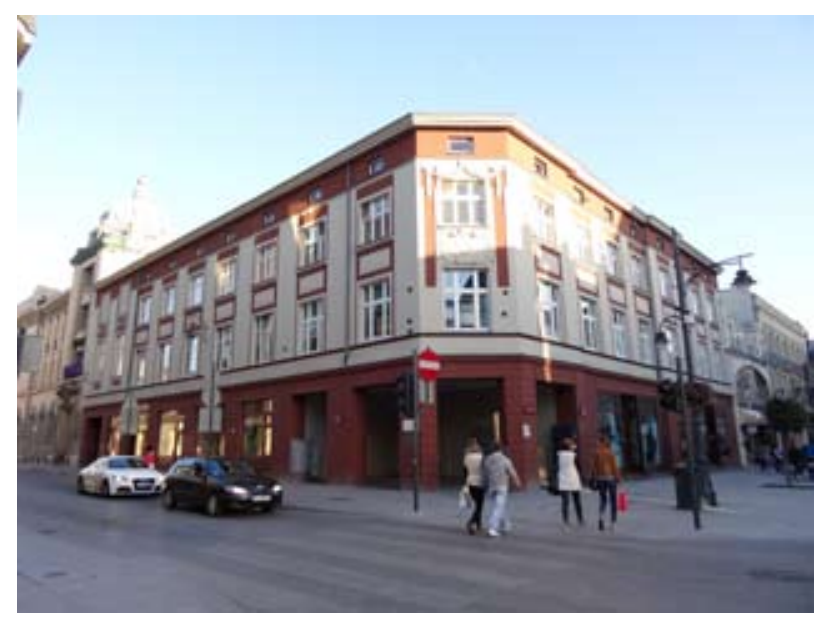

Former House of the Assembly of Master Weavers

Originally it was a one storey brick house with a hipped-gabled roof covered with tiles. It served as a meeting place for master weavers, members of the most prominent professional guilds in the city. The building was designed by Ludwik Bethier and erected in 1839. The date 1892, visible in a cartouche over the soft arches of the corner tower - symbolises the year when Emil Schmechel opened his first shop in a building constructed The present building was erected in the years 1906-1911. The Schmechel Department Store sold goods "for any budget"

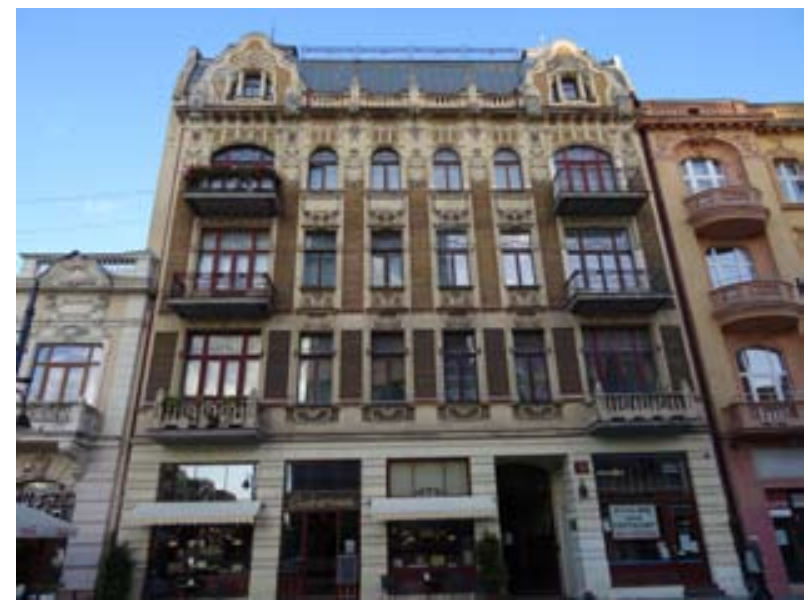

The Schicht family tenement house

The building was designed by a popular architect Gustaw Landau-Gutenteger and erected in 1904 for Mr and Mrs Gustaw and Alwina Schicht.

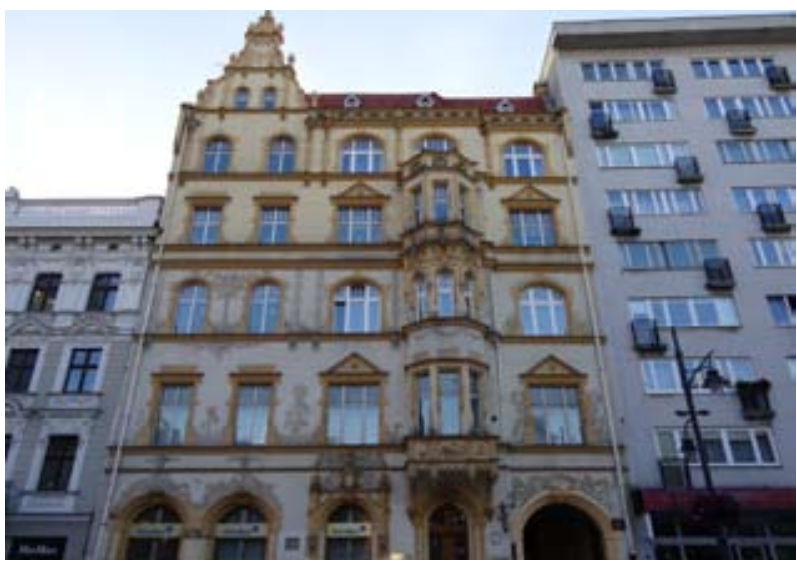

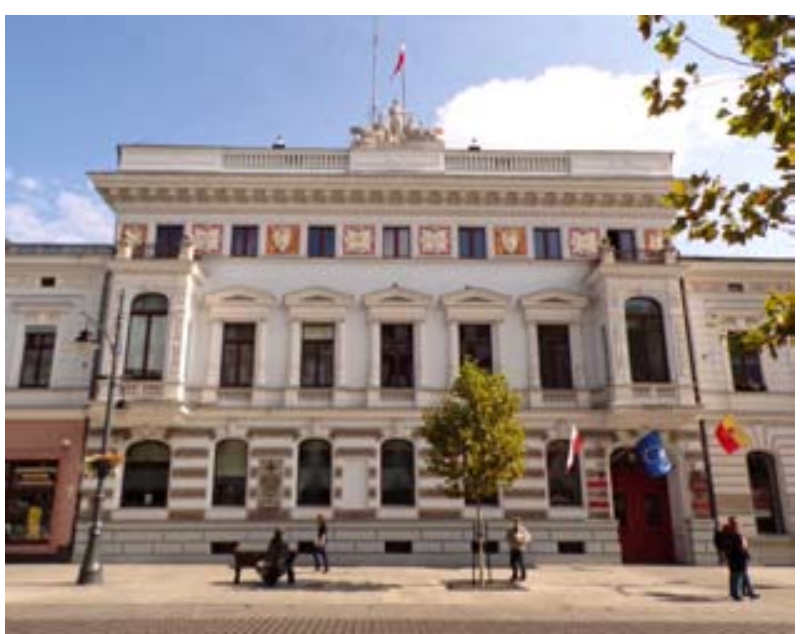

"Juliusz Heinzl Palace"

The palace was designed by Otton Gehlig and erected in 1880 . Today the building is used by the Town Hall and Łódź Voivodship Office. (C) By Kamiladob- Own work, CC BY 3.0

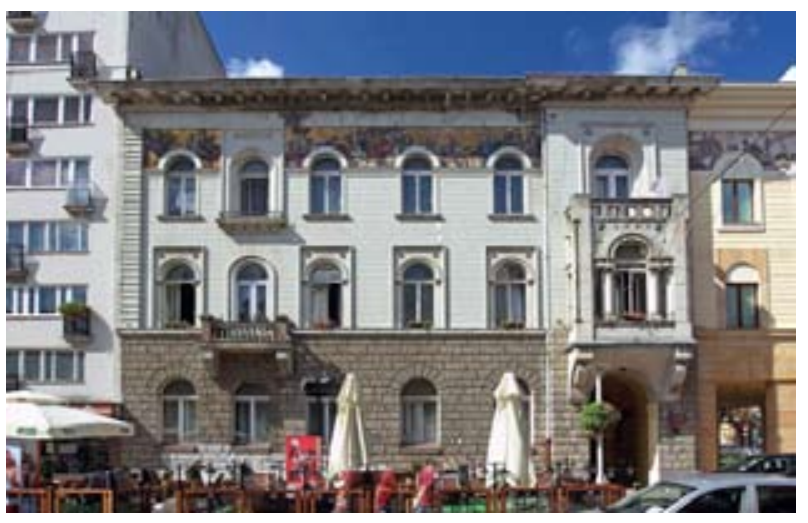

Juliusz Kindermann's Palace

Designed by Viennesse architect Karl Seidl, it was built between 1907-1909 (C) (Machlański, Piotr 2010)

The Krusche and Ender's firm Tenement

It was designed by Dawid Lande 1898-1899 



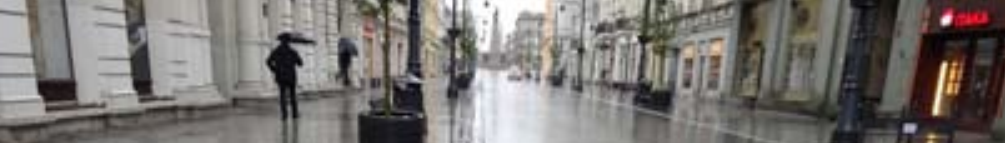
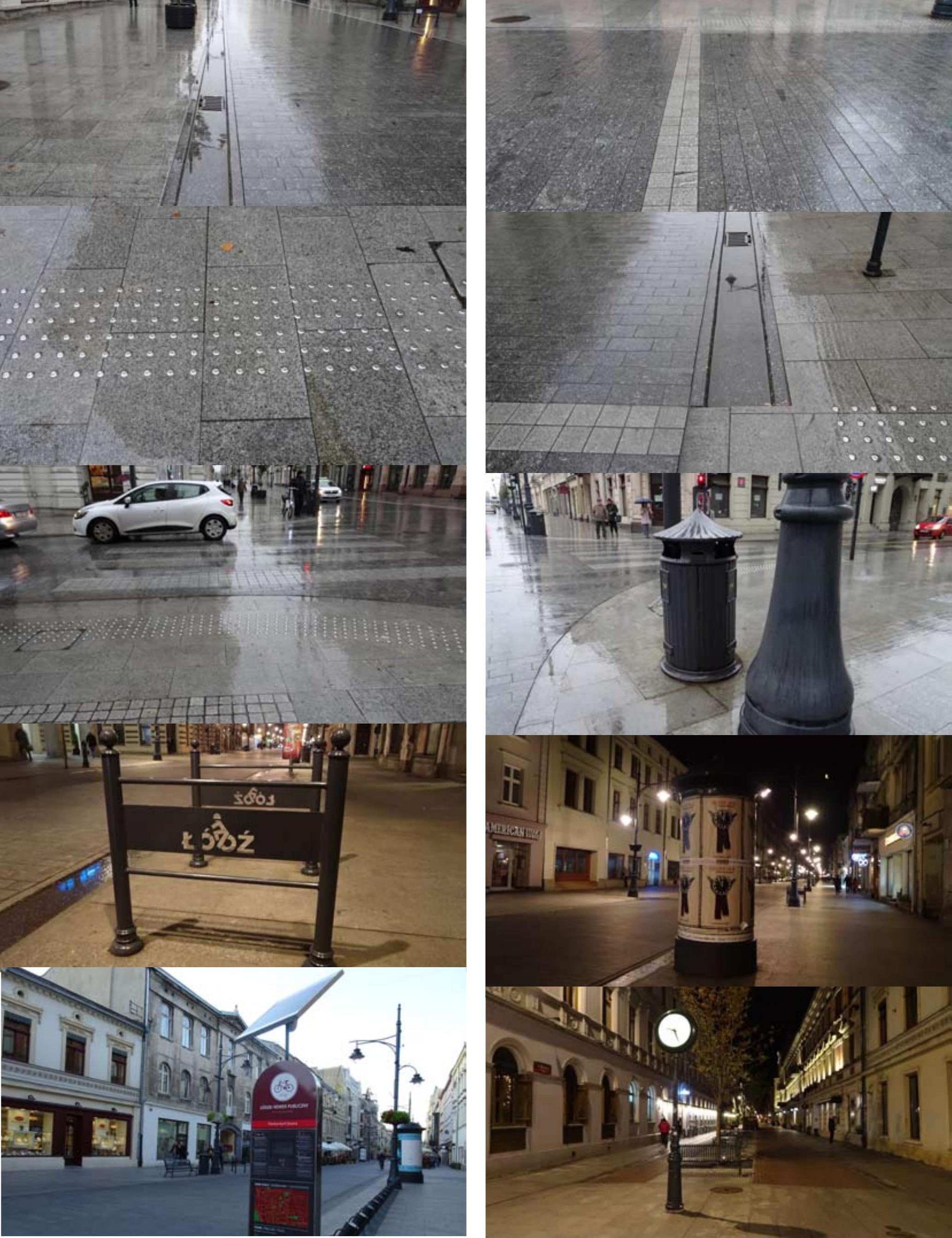


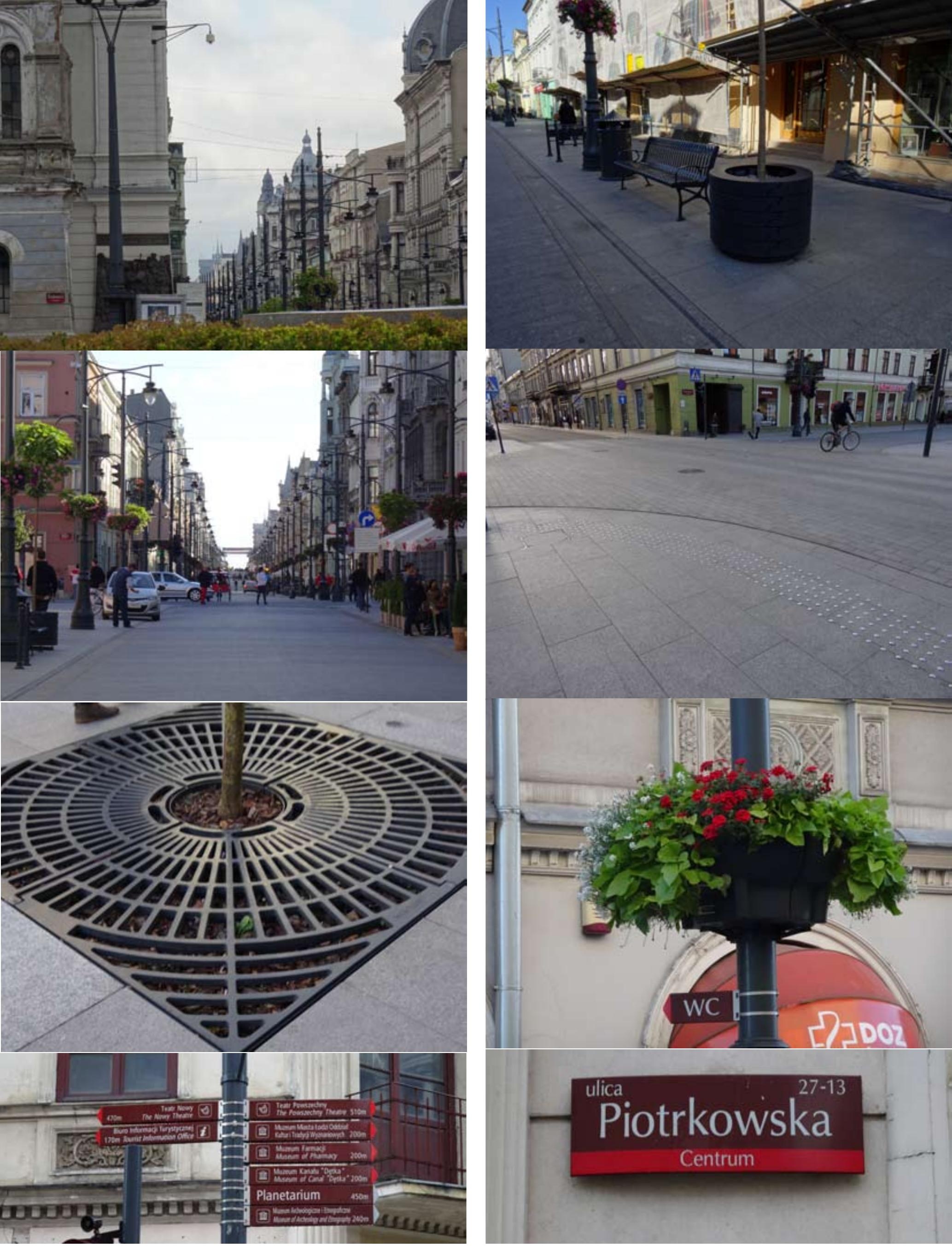




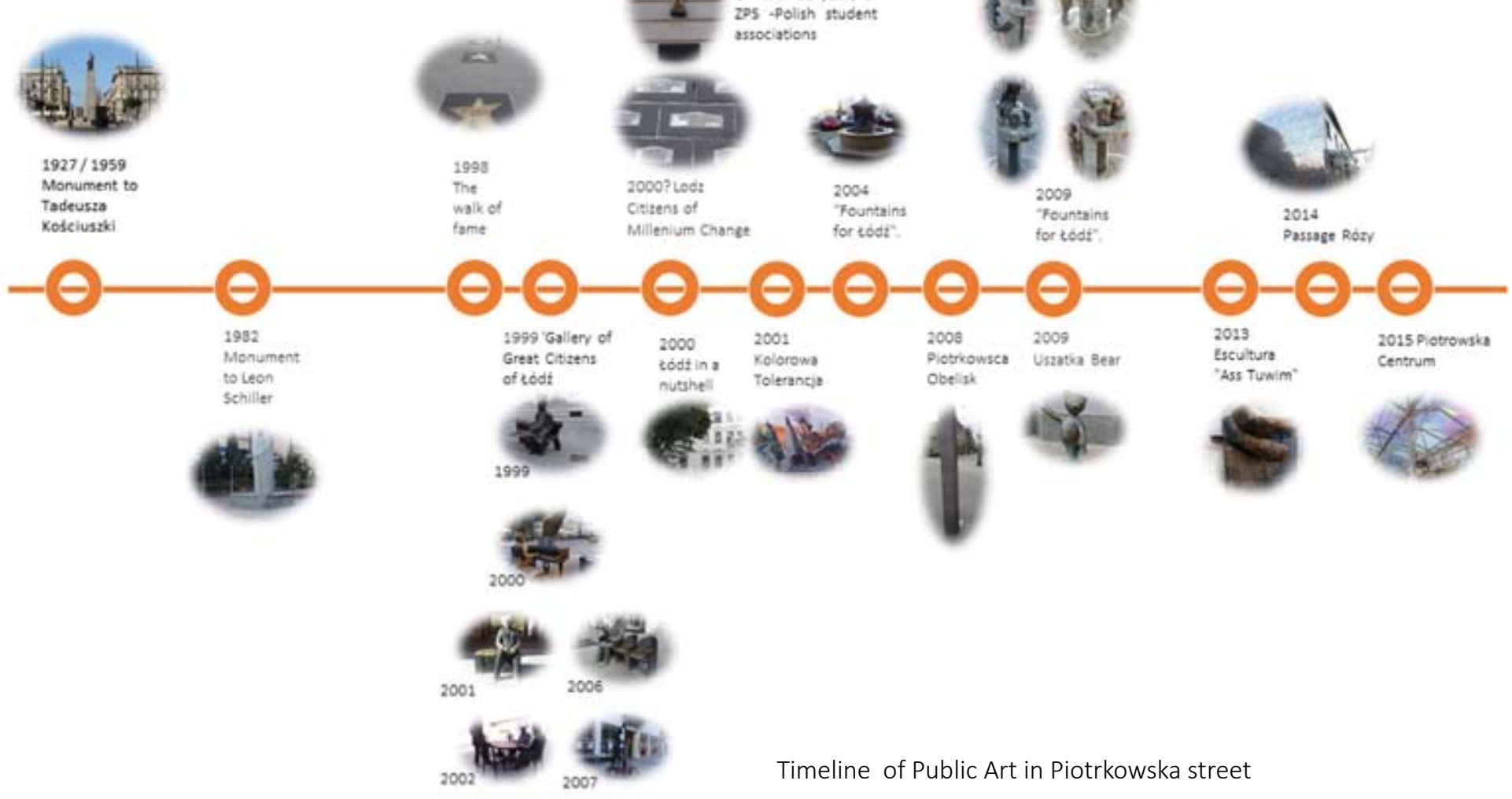

Public Art

As a great pilot project for the following Urban Regeneration projects, a clear will to "urban aestheticization" is seen on the street, not only through urban design but through various public art interventions.

Public space is structured in four planes ${ }^{3}$ :

- that of the ground,

- the vertical (not exclusively of facade);

- the plane of the air and

- the plane that can be called zenital.

The most studied is the horizontal plane, built from infrastructures, elements of urban service (lighting, vegetation, signage, etc.) and interfacing with urban systems (water, electricity, gas, etc.), with the omnipresent elements of paving.

The study of the vertical plane is reduced to the analysis of the facades, although the vertical containment of public space goes beyond the facades. Lodz is a good example of its use Urban Forms.

The plane of the air and the zenith plane are the least studied. The plane of the air unfolds its space between the vertical plane elements and the plane of the ground. While the zenith plane every day takes more strength due to the location of new energy systems (solar panels) and the gradual importance that gardens acquire on the buildings roofs.

3.- About the definition of the planes of the public space (ground, vertical, air and zenith) we refer to our previous works (Remesar, Antoni 2011; Remesar, Antoni; Ríos, Marien 2018; Ríos Díaz, Marien 2017) 


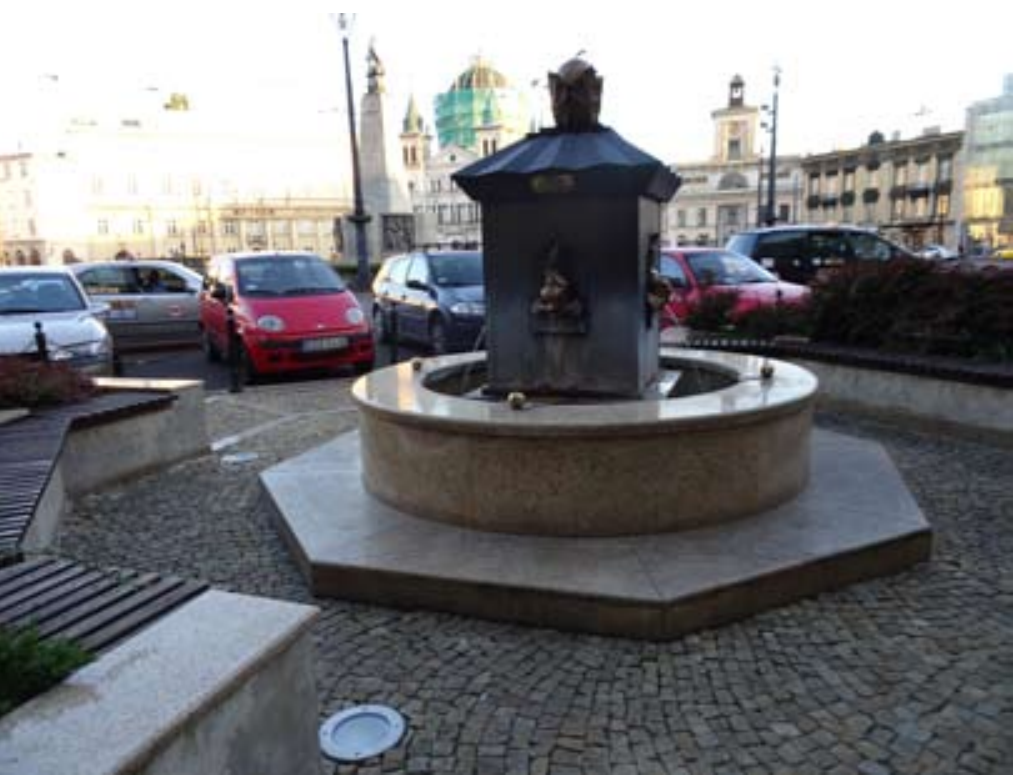

\section{Fountain at Wolności Square (1930 / 2004)}

It was built in the 1930s by students of the School of Crafts of the Salesian Society in Łódź. Closed and forgotten for many years, it regained its place in the city thanks to the "Sources for Łódź" project. It was rebuilt with the original elements and with the consent of the city conservator. On July 15, 2004, Łódź Mayor Jerzy Kropiwnicki ceremoniously unveiled the restored fountain.

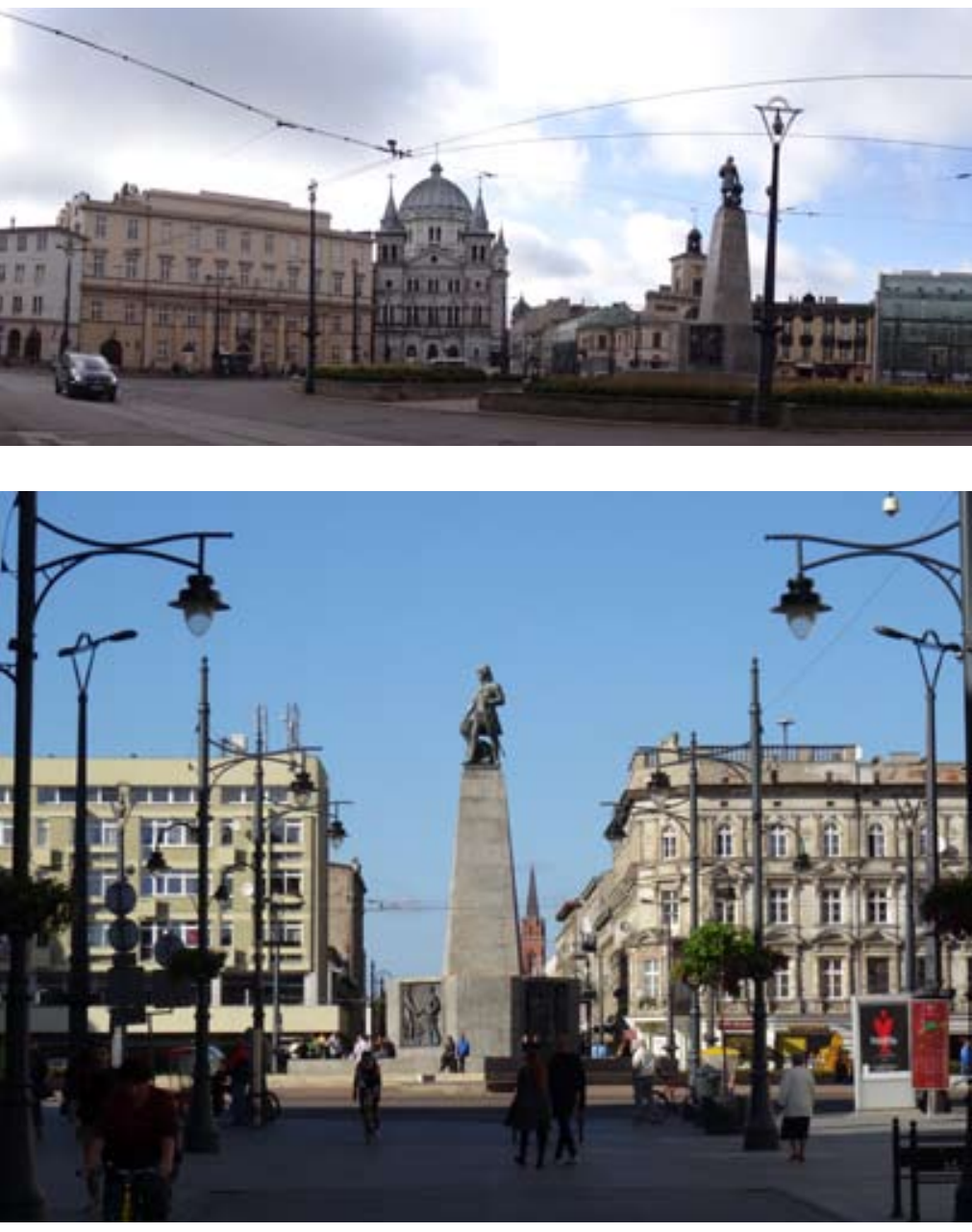

Monument to Tadeusz Kościuszko (1927/ 1960)

The decision to build the monument dedicated to Kościuszko was taken in 1917 , at a solemn meeting of Łódź City Council on the occasion of the centenary of his death. But work stopped until 1918 when Poland regained its independence.

It was decided that Wolności Square would be located in its current location. In 1921, a competition for the design of the monument was announced, which was decided a year later, but none of the works submitted at that time were enabled for execution. A second competition was announced in 1923, with Zdrowie Park as the monument's location, which should also be renamed People's Park. 

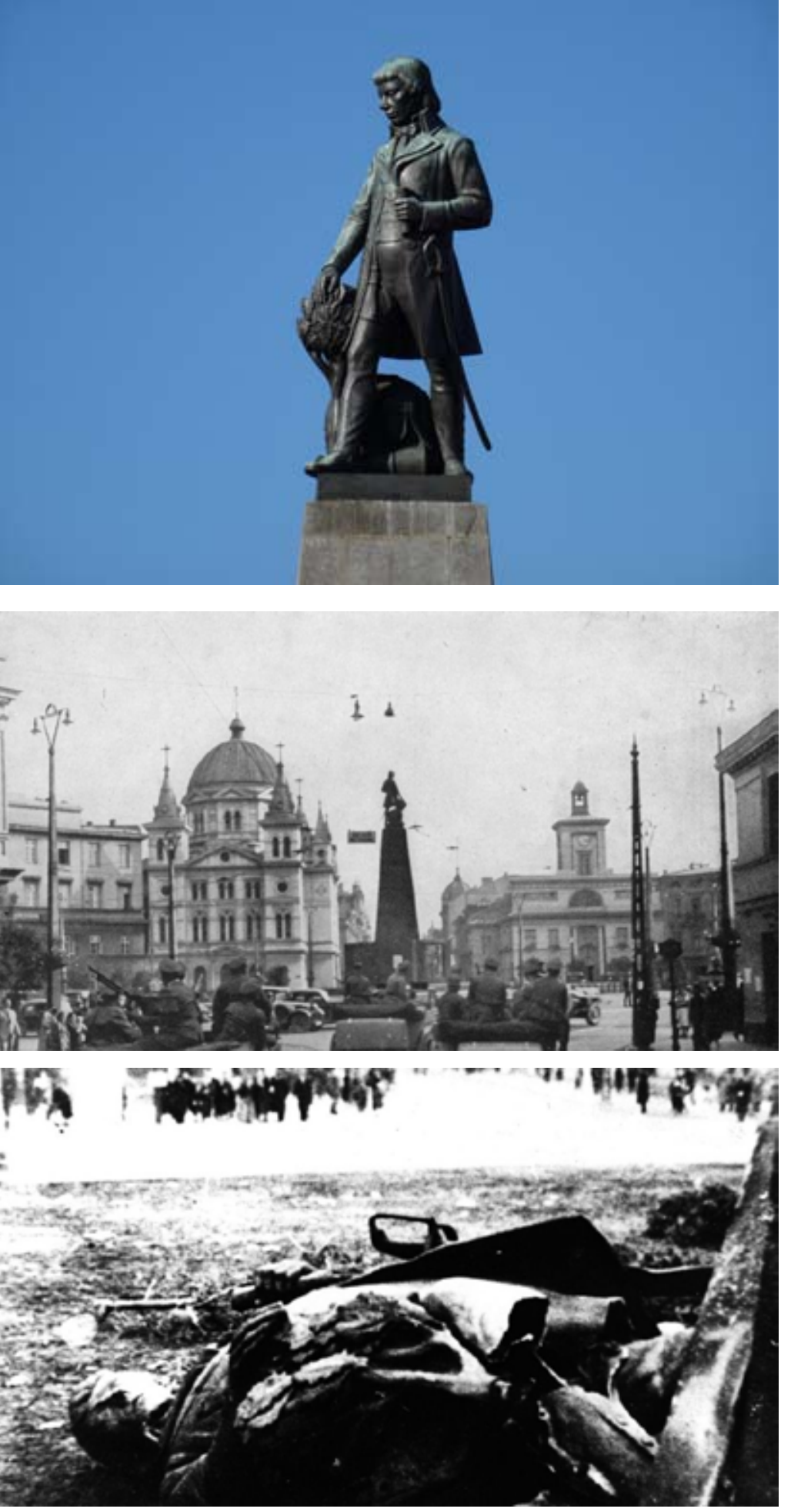

On the 80th anniversary of the outbreak of World War II, IPN's branch in Łódź features mostly unpublished photographs from the occupation period.

Above: Parade of military vehicles during Hitler's visit to the city

Below: Destruction of the statue

(C) Institut de Remembrance National Branch a Łódź
However, the winning project for Władysław Czapliński was not implemented.

As a result of another competition in 1926, the project was selected Mieczysław Lubelski was selected, the first stone of the monument was laid in May 1927 and the work lasted about 4 years.

In 1940, the Nazis demolished the monument and erected an obelisk decorated with a swastika, at the top of which was a figure of a stylized eagle.

In 1946, a competition for the reconstruction of the monument was announced. Edward Nowicki's design, which represented the figure of Kosciuszko on horseback, did not, however, gain the approval of the city authorities.

In 1956, the Committee for the Reconstruction of the Tadeusz Kościuszko Monument was set up. The theme of the figure will reappear and, finally, it was decided to restore the monument in pre-war form. Mieczysław Lubelski was invited to make a copy even though he resided in Britain. Due to his advanced age, the sculptors of Łódź - Antoni Biłas and Elwira and Jerzy Mazurczyków helped him.

The artwork was overseen by the Artistic Committee of the Ministry of Culture and Art, which issued a permit to begin work on June 2, 1959.

The monument was unvelied on July 21,1960 , the eve of the national holiday of the Polish People's Republic. 

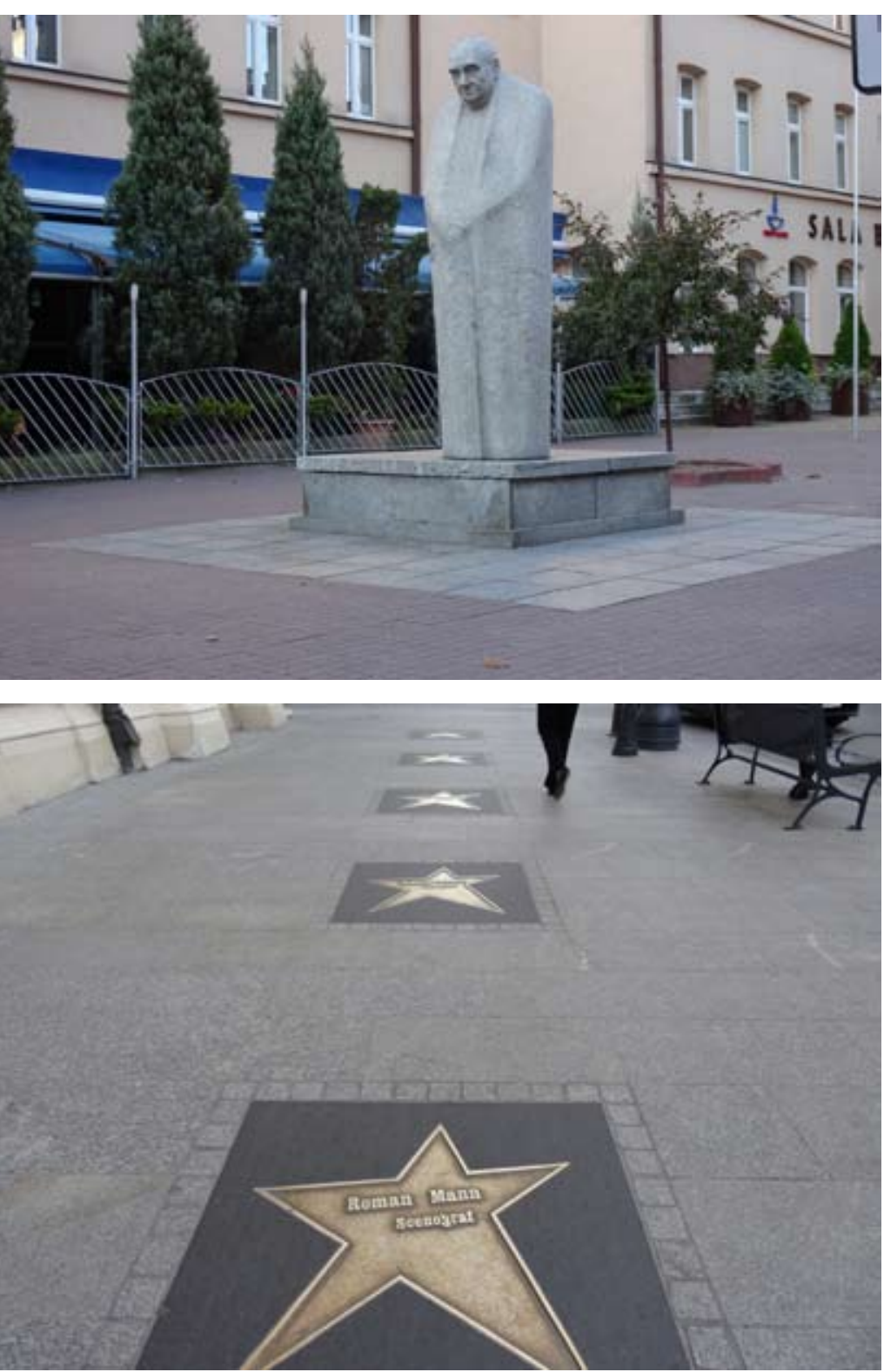

\section{The Walk of Fame (1998)}

It consists of a set of bronze stars on the floor in the style of the Hollywood Walk of Fame. It is dedicated to recognizing great Polish artists from the entertainment world, especially from the world of cinema, since Lodz became the centre of Polish film production and headquarters of the National Film School. The city's film credentials were given a top class nod in 2017 with Łódź being added to the UNESCO Creative Cities Network as a City of Film. Walk of fame was designed by Andrzej Pągowski in 1998.

\section{Gallery of Great Citizens of Łódź (1999 - 2007)}

It is a project by Marcel Szytenchelm, actor and director. The idea was to take the form of statues on Piotrkowska, dedicated to the great and good of (what was then) Poland's second city (when the programme started, today the third).

So far the following sculptures have been placed

1999 Julian Tuwim's Bench work by the sculptor Wojciech Gryniewicz, came up with a castbronze figure of the literary hero Julian Tuwim. Unveiled on April 10, 1999, it was a roaring success, with the bench Tuwim is sat on becoming a popular meeting spot for canoodling couples. 


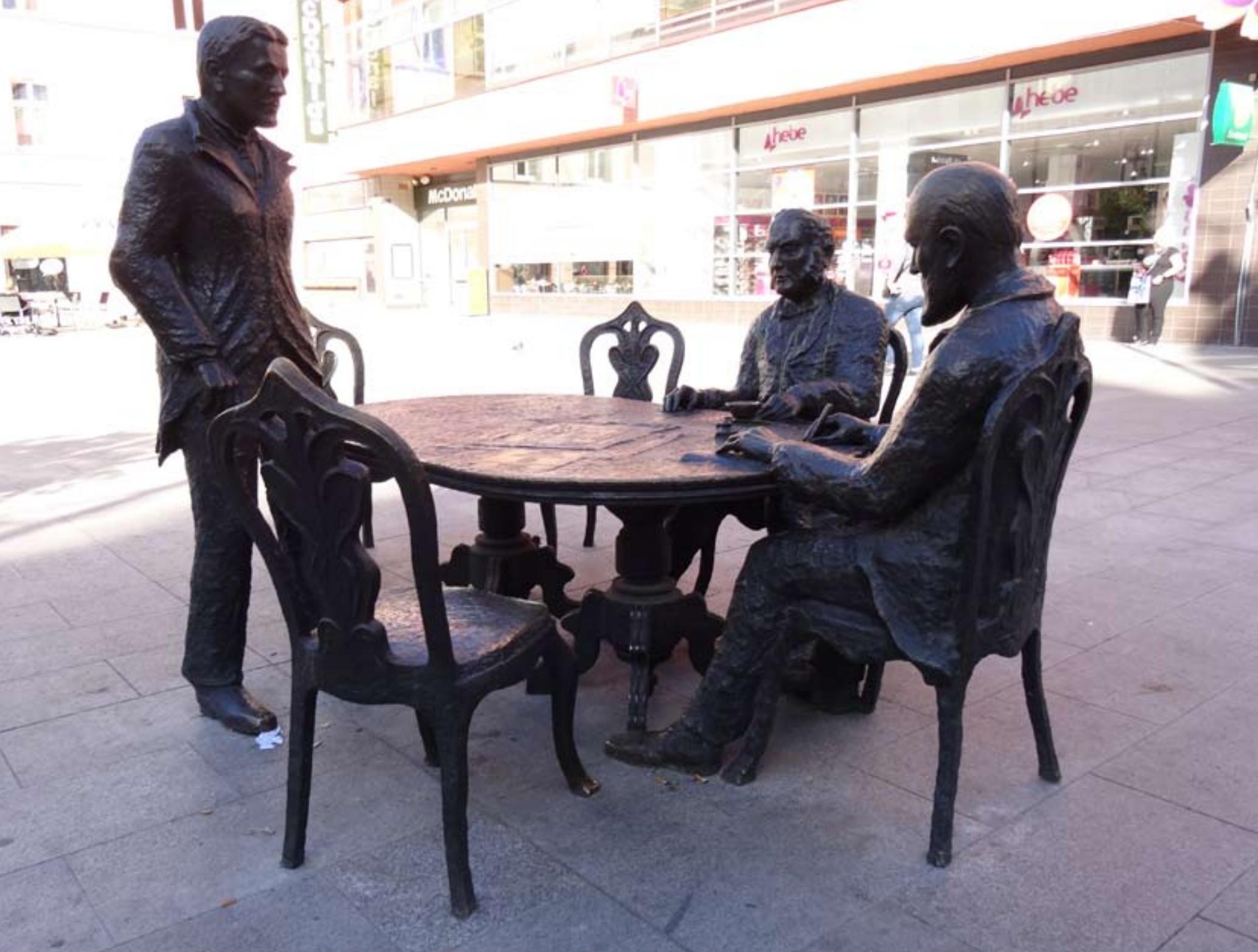

2002 The Industrialists work by the sculptor Robert Sobocinski, a statue of Izrael Poznański, Karol Scheibler and Ludwik Grohman seated around a table signing an agreement.

2006 Jaracz's Chair Robert Sobocinski?

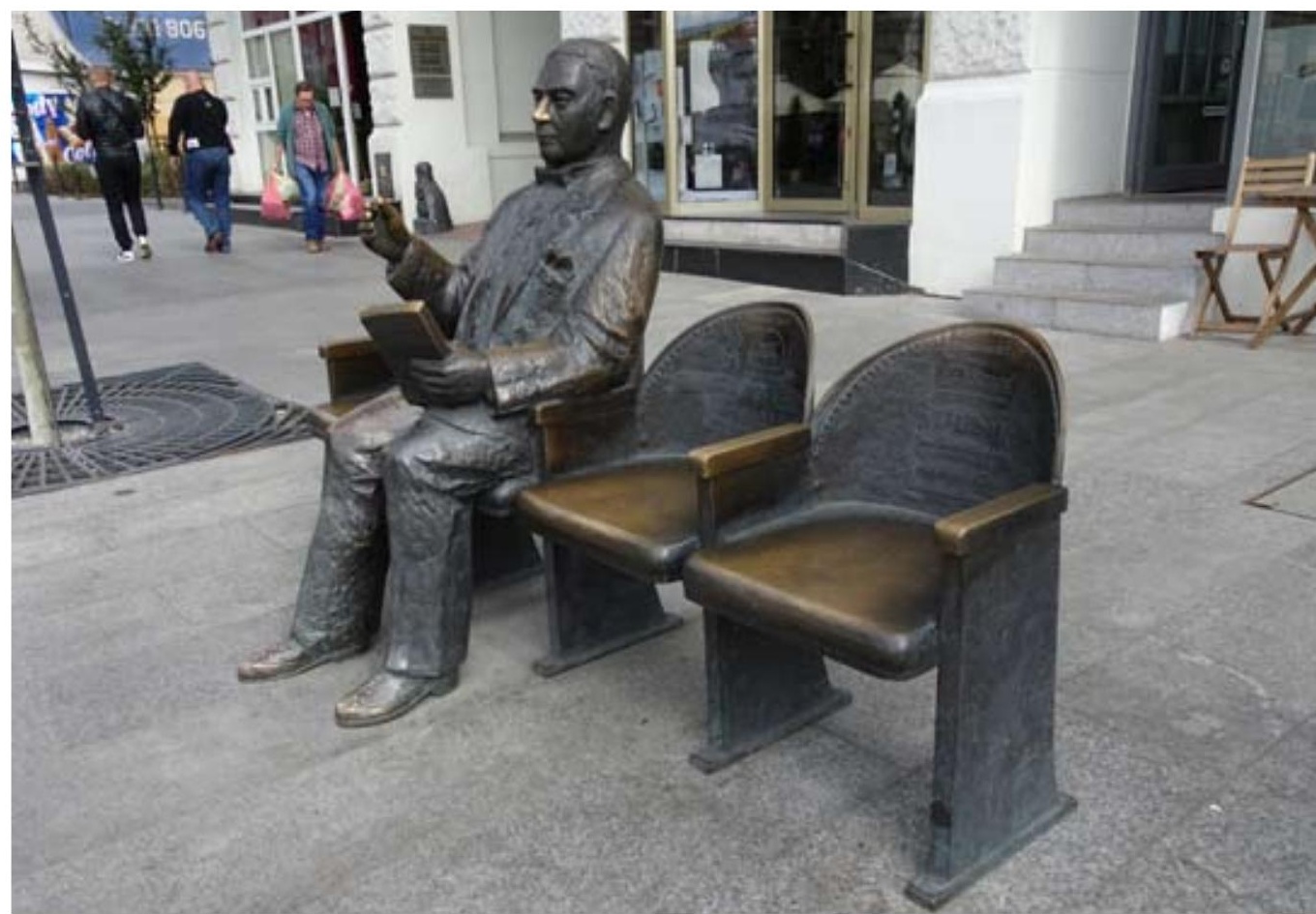


taking as a theme characters from polka cartoons. So far she has created: Uszatka Bear Statue (2009)

- Sculpture of the little penguin Pik-Pok (2010) • The Strange World of Cats Philemon and Boniface (2011)

- Sculpture of the Heroes of the Movie Enchanted Pencil (2011) • Plastuś (2012) • Three Bears (2012) • Wróbelek Ćwirek (2013) • Maurycy and Hawranek (2013) [5] • Ferdinand the Magnificent (2015) • Bear of Colargol (2018). The first sculpture in the series, Uszatka Bear Statue, is located in Piotrkowska.
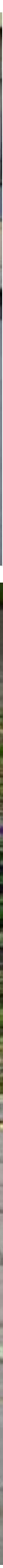


\section{Piotrkowska's Fountains ${ }^{4}$}

As part of the "Sources for Łód" program, a specific project for the street was proposed in 2009. The authorsofthesculpturesareMagdalenaWalczakandMarcinMielczarek, andthearchitecturalconcept was developed byKrzysztofWardecki.The projectcontractorisWaterSupplyandSeweragePlant, Łódź.

There are fourfountains distributed along the street that takeas their motifimages of childrenand fish.

\section{Works in the vertical plane of Public Space}

Łódź has been called "The Polish Manchester" in reference to the importance of the textile industry; "The City of Four Cultures" in reference to the meeting of Polish, German, Jewish and Russian culture. "The Capital of Polish Cinematography" in reference, as we have seen, to being the seat of the Polish film industry or "The Promised Land" in reference to the film of the same name directed by Andrzej Wajda in 1975.

Being in the city, after a few minutes walking through, we did not perceive a relationship with the four previous denominations and there is no other option but to label it as "The city of walls". A few minutes later, this name will change to "The city of murals". In the central part of the city there are many urban voids that reveal a multitude of party walls. In the areas of urban growth in residential estates, large blind walls have been prioritized on the sides of the blocks. In the centre these walls produce a feeling of neglect and abandonment. Some of them are used as support for billboards. Others are intervened with murals. Urban Forms, a cultural foundation, is responsible for developing the mural project. Urban Forms Foundation was created in 2009 by art historian Michał Bieżyński and actress Teresa Latuszewska-Syrda 5 .

The history of the Urban Forms Foundation is slightly longer and more complicated. In 2008, Teresa Latuszewska -Syrda established the Street Art Support Foundation "Outline". Then in 2009, on her initiative, the concept of the gallery called the Zachodnia Gallery was formally presented to representatives of the City Hall and the City Council. Soon the concept was changed as a result of the administrative decision to demolish some buildings along Zachodnia and Kościuszki - the street that was to be the location of the gallery. A new concept of the gallery located in the wider centre of the city was named the Urban Forms Gallery. Since 2011, the Foundation has operated as the Urban Forms Foundation, headed

4.-Writing from Barcelona, I cannot fail to mention- let no one be bothered- the fact that the fountain programs, with realistic and "kind" sculptural figurations (children, animals, story characters) are not new. For example, in Barcelona, between 1912 and 1917 a font program was developed for the Ensanche. Program that will be repeated in the 1920s, and even for the 1992 Olympic Games, the "Olympic Fountains" program (1994) was implemented with sculptures of boys in the attitude of practicing a sport.

5.- As Teresa Latuszewska-Syrda, director of the Foundation, explains "We focus on broadly defined city culture and on organizing, promoting and supporting independent artistic initiatives in public space. We want to change city space by raising its quality and aesthetics. We see artistic activities as important tools in education and social revitalization. We want to promote "living" culture and art, direct them towards people and make it possible for them to take an active part in organized events. We propagate every activity that aims at revitalizing our city and county as well as the whole country through artistic creativity... Our fundamental mission is to saturate the cityscape with creative, multi-layered and modern art that would improve the current image of Lodz, giving it a truly artistic and original value. The main tool to reach our aim is large format painting done directly on the side elevations of buildings. The reason is that it changes the appearance of a given space permanently... Urban Forms Gallery is the main project of the foundation. It is a permanent street art exhibition in public space of Lodz". 
Lódz "city of murals"
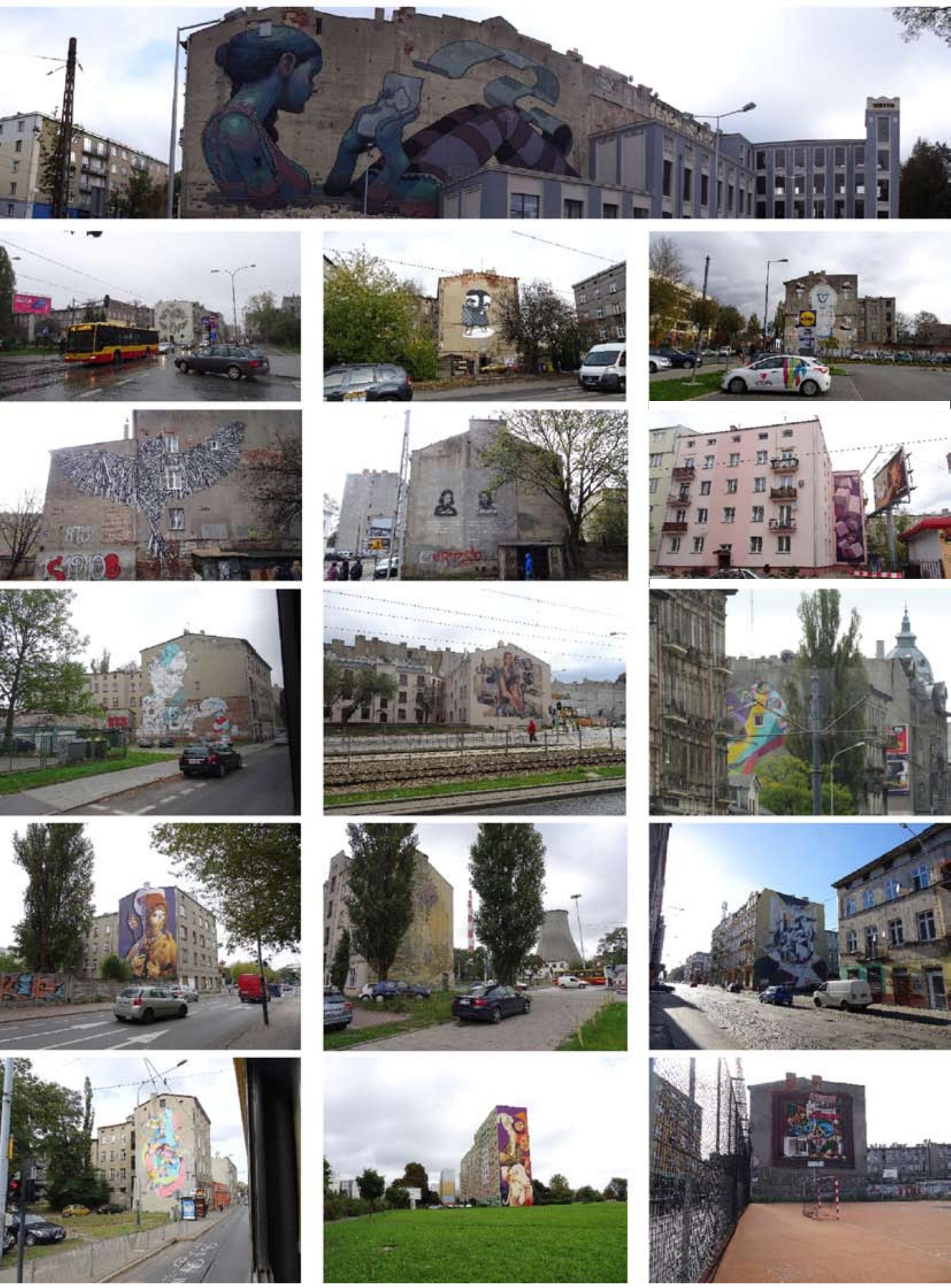
The idea of painting such a large fresco was born in 1996. It is modelled on similar paintings on the walls, among others Lyon, Barcelona, Rome. The mural was created from August 28 to November 3, 2000. The author of the project is Krzysztof Jaśkiewicz

The fresco imitates the wall of the building with balconies, windows and shops, in which 31 of the most famous and distinguished figures for Łódź appeared. This list was selected as a result of the competition "And you can go down in history" organized by the city architect Piotr Biliński and the Łódź branch of Gazeta Wyborcza. The final selection of 130 candidates for the mural was made by a jury to which the rectors of the universities of Łód $Ł$ were invited. The mural is completed by the figures of the weaver from Łódź, the anonymous Jew and Lila Fontelli, a street singer.

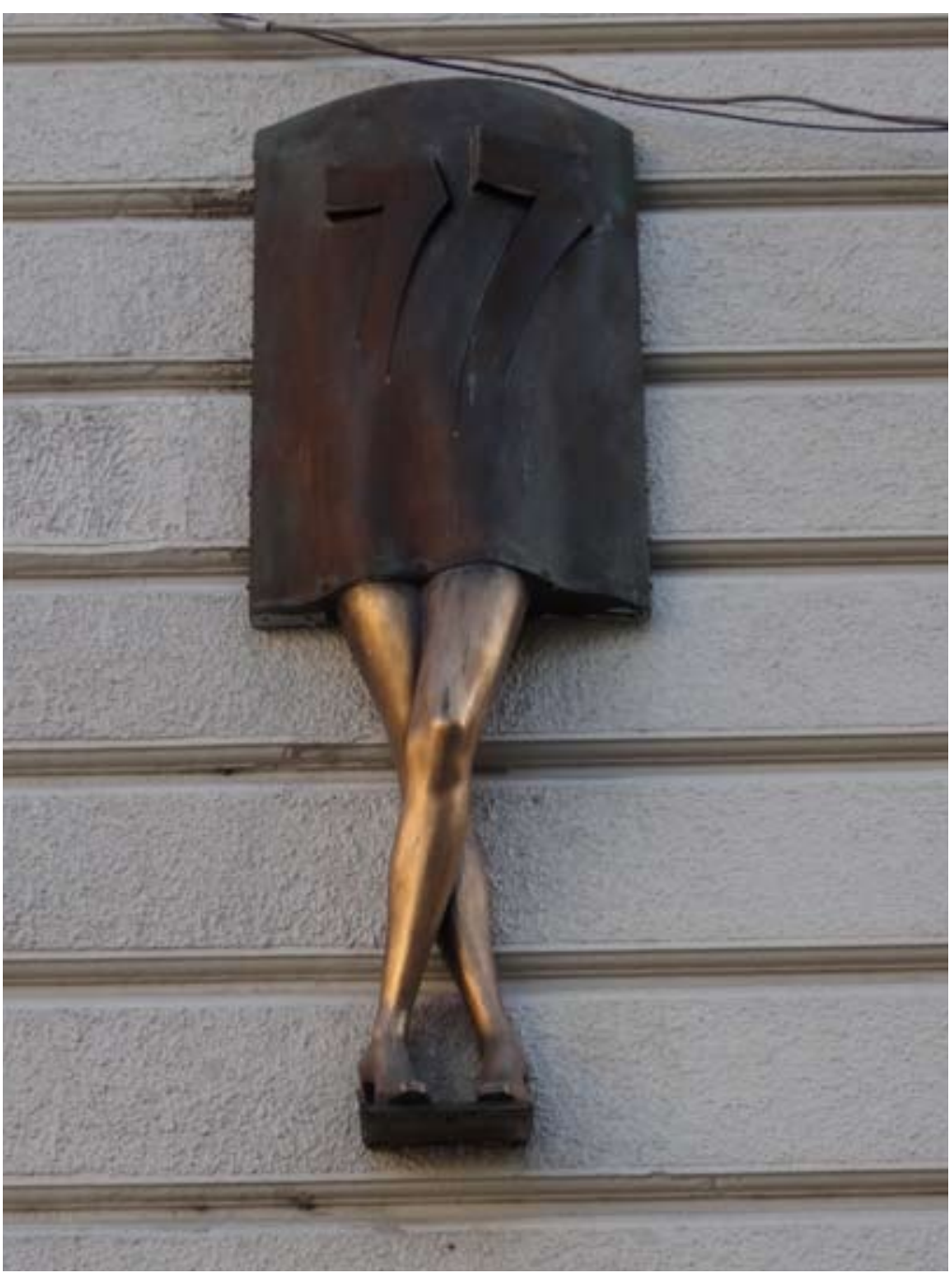

\section{On the $\mathbf{5 0}$ years of ZPS -Polish student associations (2000)}

The Polish Students' Association was founded in April 1950 in Warsaw. The decision to form the organization was taken by the Congress of Polish Students meeting in the auditorium of the Warsaw University of Technology on April 16, 1950.

\section{Kolorowa Tolerancja - Łódź zwycięska (Victorious Łódź) 2001}

Colorful Tolerance is a cyclical festival conducted in Łódź since 2000. It aims to oppose intolerance, xenophobia and vandalism. Every year, schoolchildren, students, journalists, politicians, civil servants and numerous non-governmental organizations take part in the campaign. During "Colorful Tolerance", insulting inscriptions on the walls are painted over. 


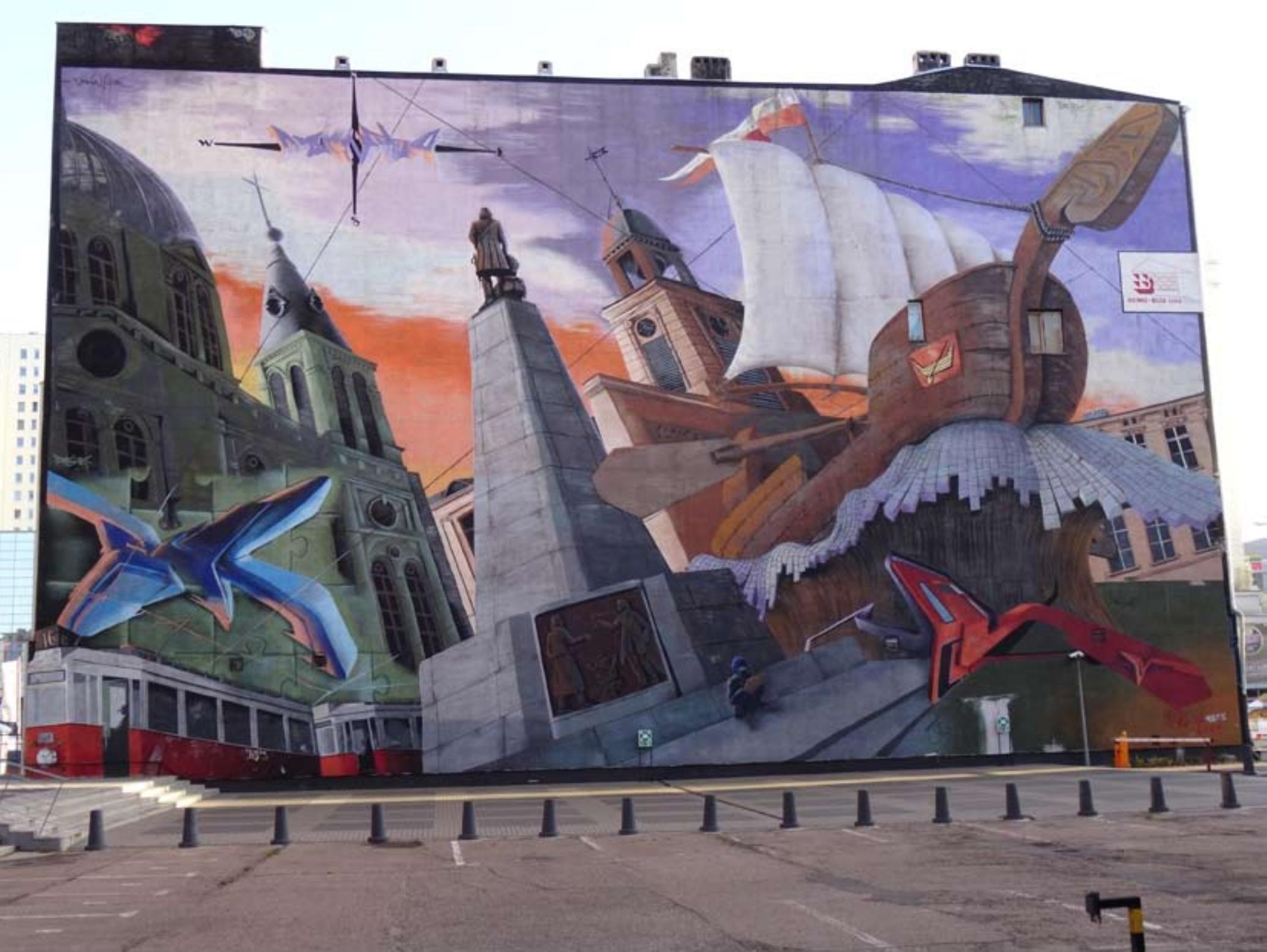

The initiator of "Colorful Tolerance" is Joanna Podolska, journalist of the Łódź editorial office of "Gazeta Wyborcza". It is organized by the Tolerance Institute Association which operates in Łódź.

At the 2000 festival, the idea of painting a large mural appeared in the last building in northern Piotrkowsca. The idea for this painting of 600 square meters, was approved in August 2001. Work on it started in September, and the whole project was completed on November. Initially the mural was designed under a working title "Łódź Victorious," showing a ship 7 sailing on the ocean shortly after winning a battle with another, already sinking, Łódź. This idea, however, was modified, as initially seen as not urban enough, with too few elements typically associated with Piotrkowska Street. Thus, the design was changed by introducing representative elements of the street.

The authors of the giant mural are members of Design Futura. When finished in 2001, it was the largest mural in the world at the time, and today remains among the largest graffiti murals in Europe. It entered the Guinness Book of Records and for a time was the largest graffiti in the world

7.- Łódź in Polish means "ship" and therefore the city coat of arms is an example of talking arms, as it represents a ship (łódź), which alludes to the name of the city. 


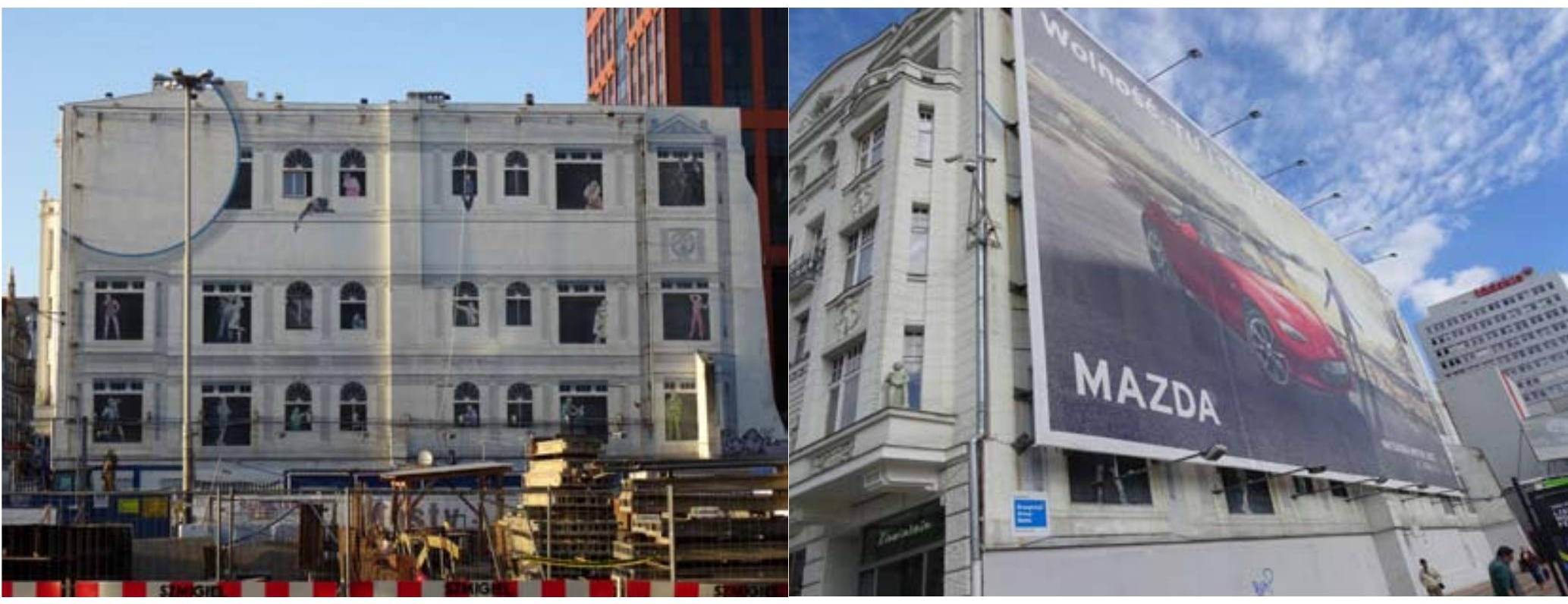

Untitled (2001?)

The party wall on which the mural was painted belongs to the "House of Bechtold" designed by Wolf Szereszewski and built for Ryszard Bechtold before the First World War.

The other party wall opens to Marszałka Józefa Piłsudskiego Avenue. This party wall is also decorated with a mural "trompe l'oeil" with current characters and others, dressed in 30s USA fashion. All current characters speak on the cell phone. This mural shares "times" with large commercials.

\section{Passage Rózy (2014)}

The passage Rózy by Joanna Rajkowska was created in 2013-2014 as part of the Lodz Czeterech Kultur festival with the support of the Mia 100 Kamienic $^{8}$ program; Academy of Fine Arts (porf. Zdzislwowi Olenjniczakowi), Institute of Philosophy of the Lodz University (dr. Wioletta KazimierskaJerzyk).

The first time I saw it, I immediately thought of the "Quixote", specifically in the "Knight of the mirrors" that the bachelor Sansón Carrasco incarnated.

As the author comments on her blog:

Pasaż Róży, as the title of the project for the city of Łódź and as a phrase, has two meanings for me. On the one hand, it is a reference to the location of the project - a narrow yard at the back of the tenement house at ul. Piotrkowska 3. This yard will become a passage, crossing to ul. West, where life from Piotrkowska escapes towards the Manufaktura complex. It is the idea of building a special place - a road, and thus redirecting human presence and attention. On the other hand, Rose Passage illustrates the path that passed my daughter

8.- By definition, the "City of tenement houses" program improves the living conditions of the residents of the properties covered by the program, i.e. thermomodernization (replacement of window and door joinery, insulation of roof and external walls), replacement or strengthening of ceilings, liquidation of shared toilets located outside the premises and often outside the building, renovation of facades, gate clearances and staircases, conservation works inside buildings entered in the register and register of monuments, insulation, connection to the system heat system, modernization of plumbing and electricity installations, development of public space in real estate- new yard surface, organization of greenery in real estate. 

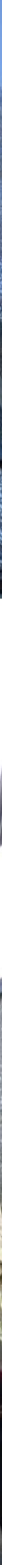

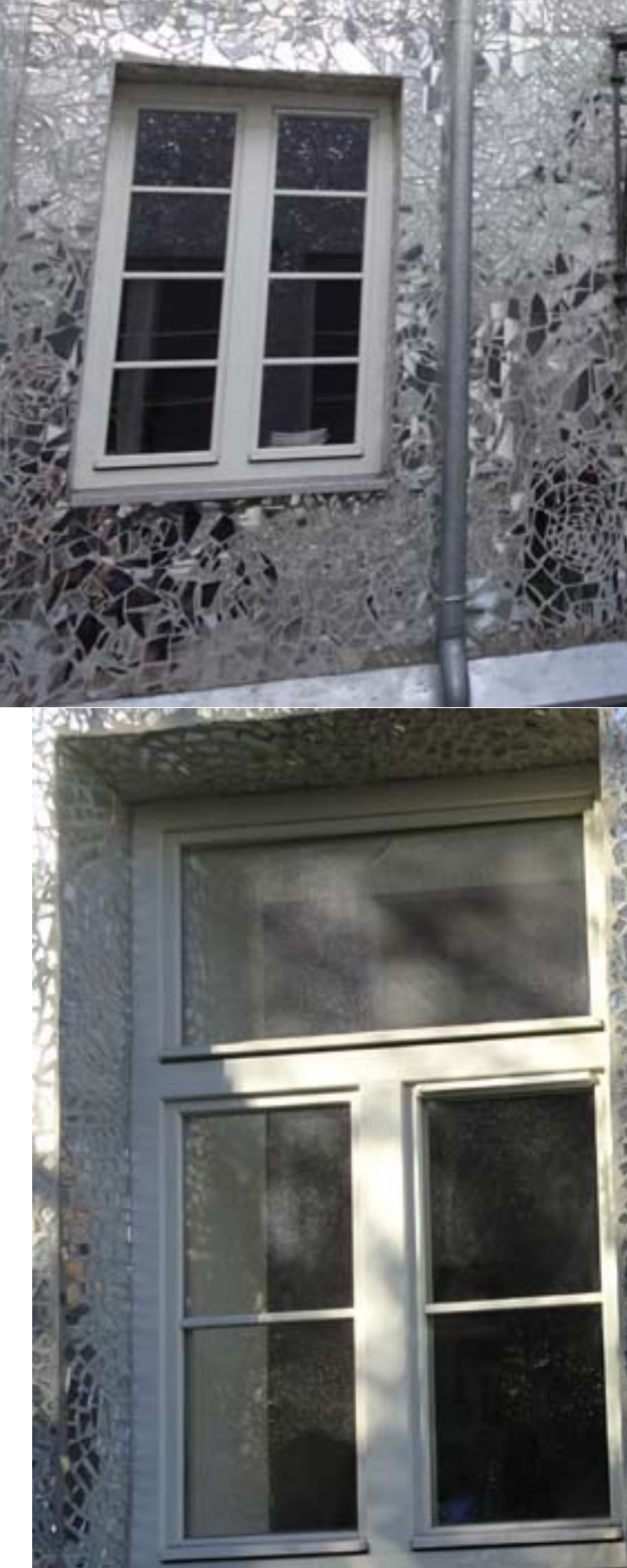
of

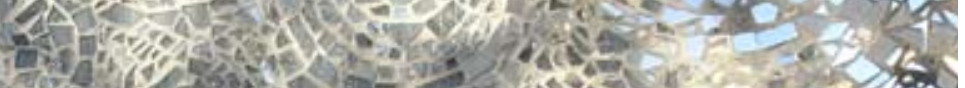

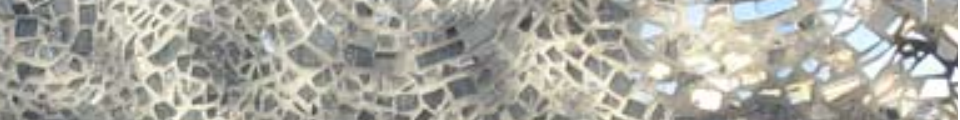
2. 0 en

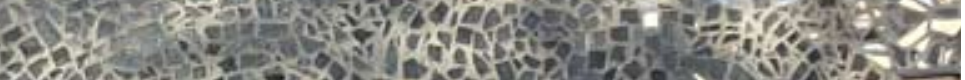

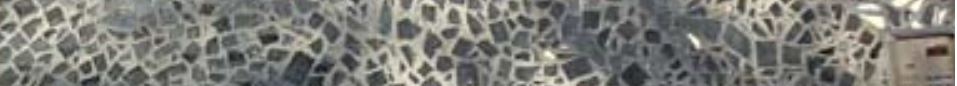

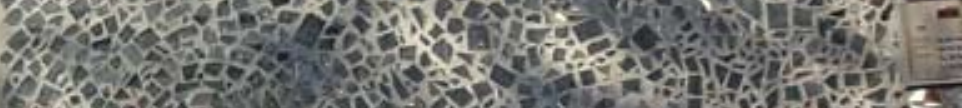

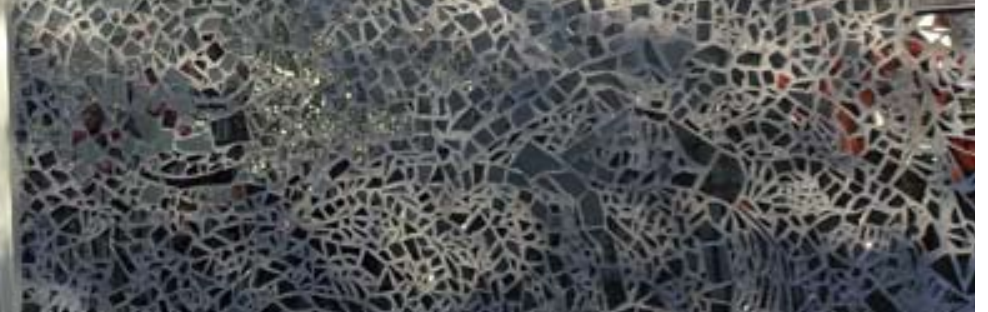
(A)

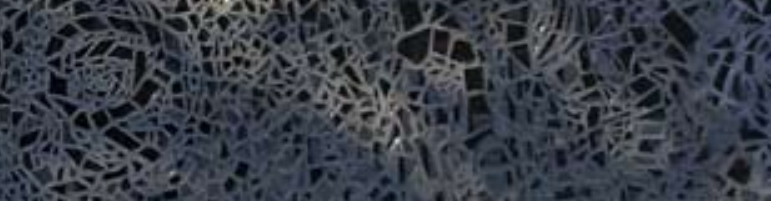




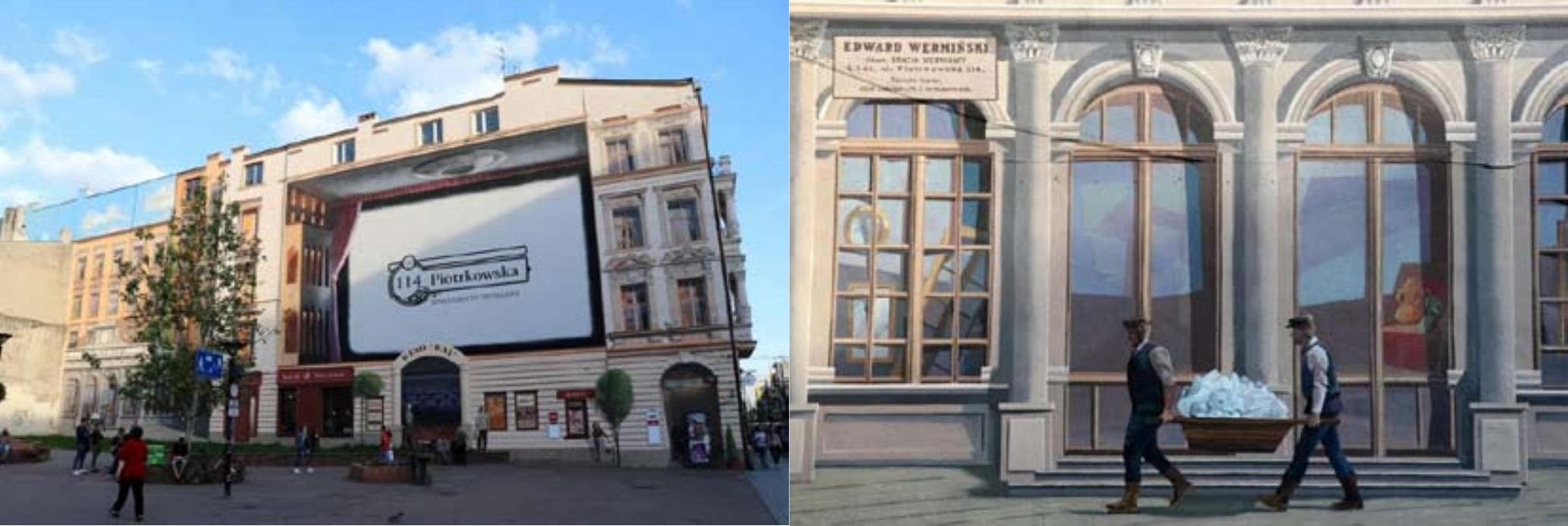

\section{Untitled (2018)}

In 2018, a large hollow wall in the Schiller Passage, one of the pedestrian streets coming out of Piotrkowska, has become a mural that has aroused huge controversy since its inception. The painting, made by the company Good Looking Studio specializing in advertising, combines two forms: an artistic reference to the terraced house where it is located and its history, as well as the advertising part located in its central part. The mural presents the façade of the building stylized as the original, as well as the building that previously housed the Atlas Sztuki Gallery. In addition, in the central part there is a cinema room with screen, which serves as advertising. Signs of historic service premises located in the building and film posters from the early 20th century were also restored. In the stylized ticket window, we can see a nice old woman: the grandmother of the current owner of the building and the originator of the controversial mural.

Two examples of public (temporary) art in the air plane

The following two works are not part of the interventions on Piotrowska Street, but they are part of the Urban Regeneration area of the Centre of Łódź. Installed in Old Market Square about 500m from the start of the street and on the edge of the old Litzmanstadt ghetto. They are a good example of how the air plane can be used for artistic interventions ... even if they are temporary.

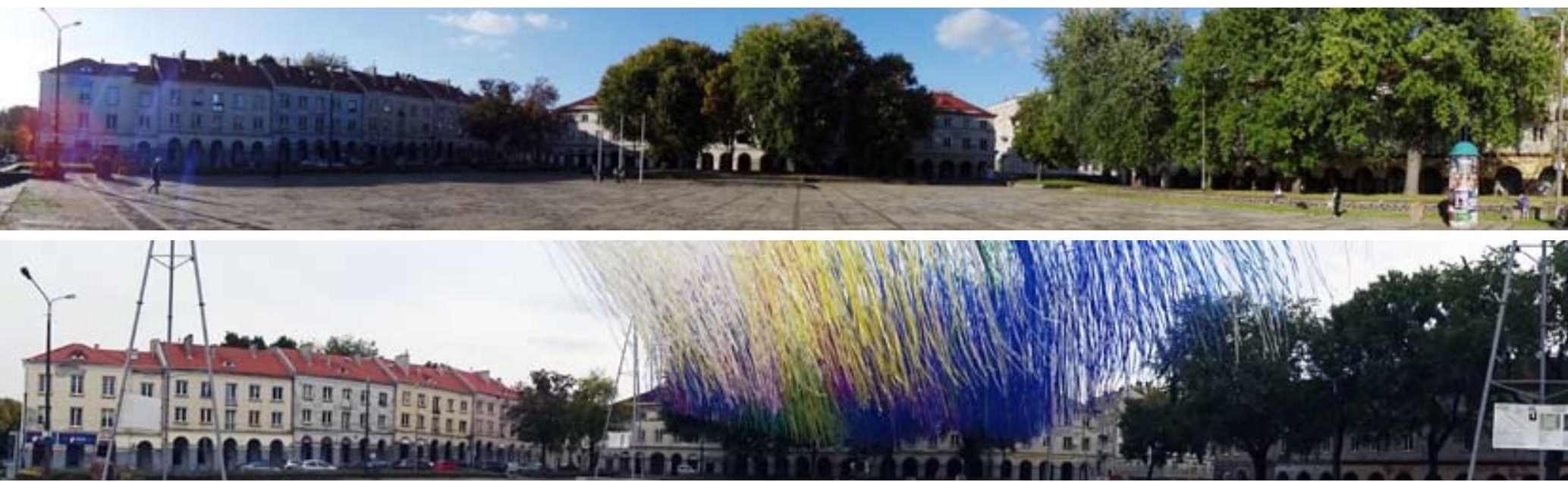

Ribbon Concerto. Installation on the Old Market in Łódź (2016)

In August 2016, Jerzy Janiszewski revived the space of the Old Market Square again. In the installation's colours referred to Łódź as an avant-garde city, which is a reference to the avant- 


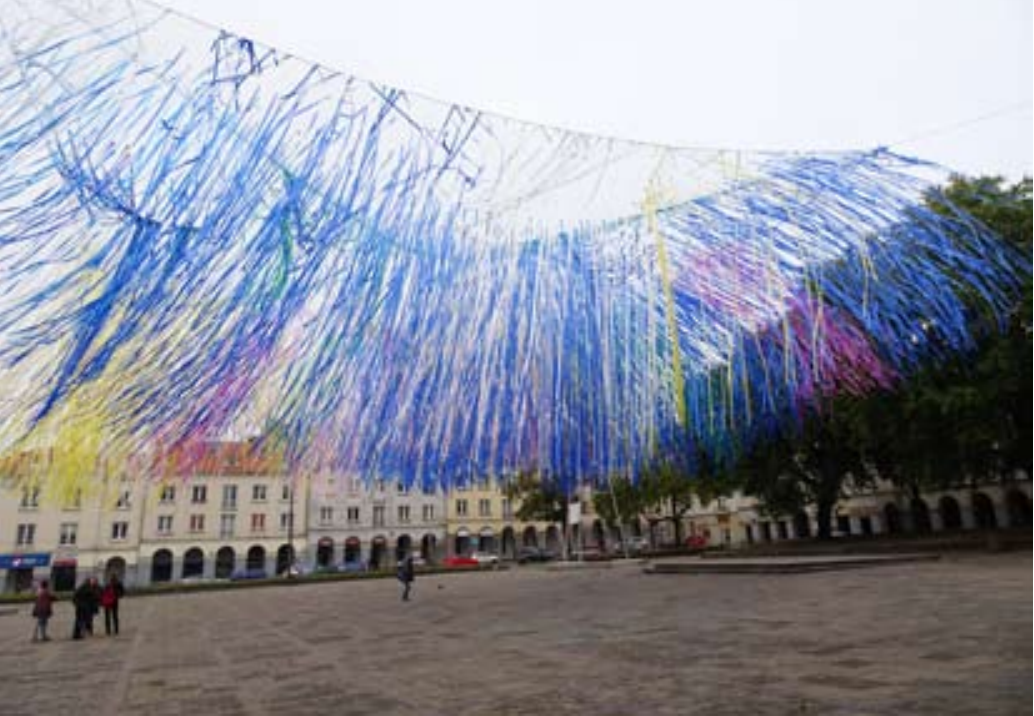

garde century celebrated this year. It is also a reference to Łódź as a place where patterned fabrics are produced and to the tradition of Łódź design. Ribbons as graphic elements set in motion, create thousands of combinations, suggest changes and transformations. Ribbons live their lives just as a metaphor of a city that is both permanent and changeable. The installation was part

\section{Untitled. Installation on the Old Market in Łódź (2017)}

The infrastructure used for "Ribbon Concerto 2" was used again the following year within the framework of the $X$ Łódz Four Cultures Festival.

Robert Rumas designed this intervention with phrases from "Polish Flowers" by Julian Tuwim, Nobel Prize in Literature.

When architecture produces Public Art. The zenith plane of the public space

If there are not many examples of the use of the air plane, we will find less of the "aestheticization" of the zenith plane. Possibly one of the best known interventions is that by Enric Miralles and Bernadetta Tagliabue on the roof of the remodelled Santa Catarina market (1997-2005) in Barcelona. The undulating architectural design benefits from the good work of the ceramicist Toni Comella. A sea of colour spreads across the deck, reproducing the sensations we experience inside the market, in which the exhibition of fruits, meat, fish, and vegetables at the respective stalls, immerse us in a universe of colour, textures and smells. The beneficiaries of this landscape, the residents on the upper floors of the houses that surround the market.

The colour universe of the Barcelona market is visible if we place ourselves "eagle eye" or, in film terminology, using aerial shots. In Łódź the situation is the reverse-low angle shots- we must raise our eyes to the sky to appreciate the soft and colourful hues of the Piotrowska Centrum Shelter, a large tram station where several lines converge and allow you to switch between them. 


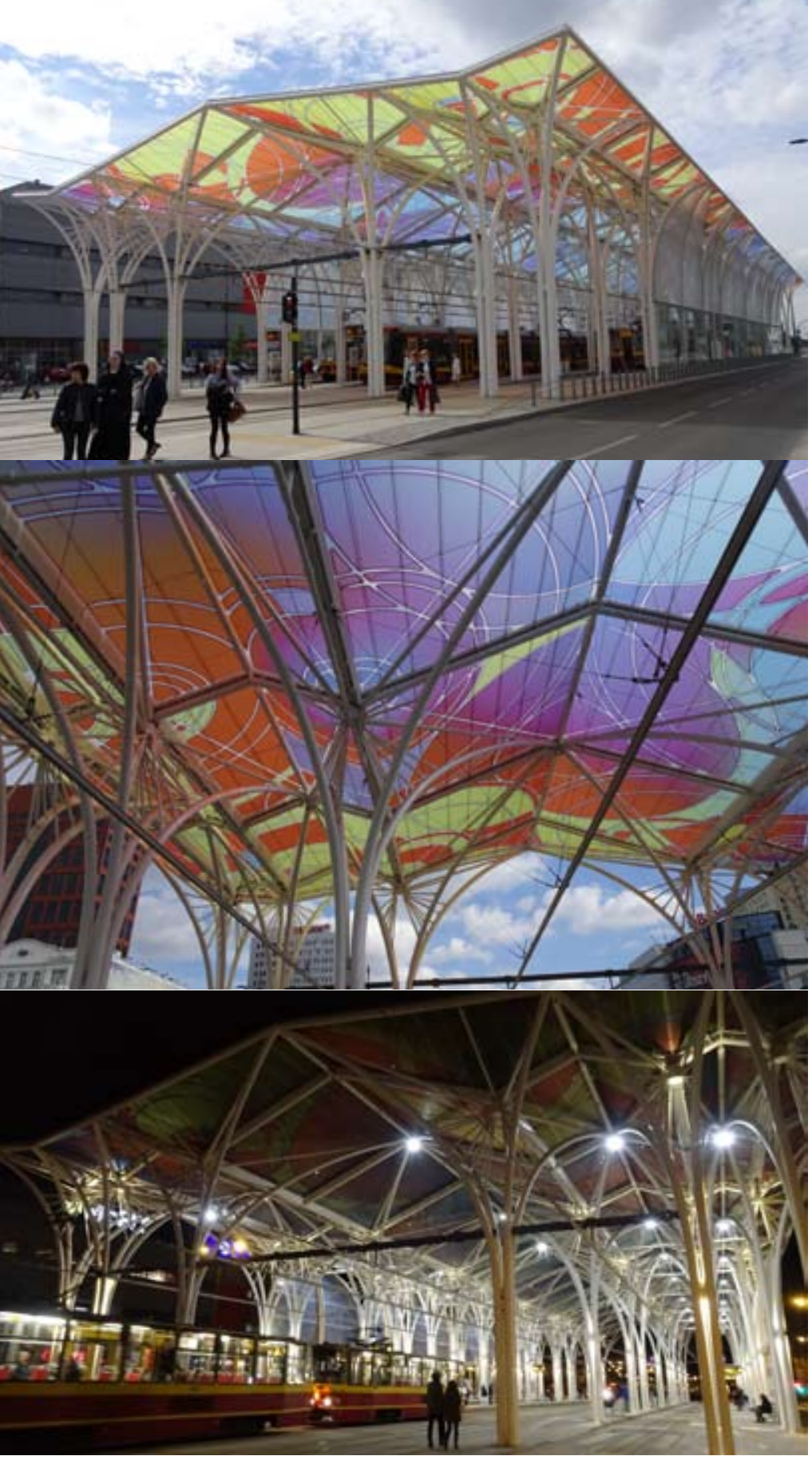

\section{Piotrowska Centrum Shelter (2015)}

The author of the shelter is architect Jan Gałecki. The station is inspired by the architecture of the Art Nouveau, which is a historic element of the city. The shed over the four platforms of the stop is characterized by soaring white pillars. The roof, created from a transparent EFTE membrane ${ }^{9}$, imitates the stained-glass technique in blue, yellow, purple and red, associated with the colours of the new Łódź logo as a creative city. The side walls are made of plastic and a membrane. For safety reasons, the use of glass was abandoned. Before the material produced in Japan with a total area of 3000 square meters reached Lodz, it was coloured in Italy- it is the world's largest roof of the building made in this technology.

\footnotetext{
9.- ETFE is copolymer, of ethylene and tetrafluoroethylene. It's refined from seawater which include $25 \%$ ethylene and $75 \%$ tetrafluoroethylene. It belongs to PTFE fluorine polymer. It shows the excellent features, and is used in various applications.

The durable film is highly transparent and very lightweight in comparison to glass structures. In fact, ETFE film generates $95 \%$ of the same light as glass, but weights just $1 \%$ its weight. In two or more layers, a pneumatic cushion (ETFE cushion) is created that is then attached using aluminium extrusions and supported by a lightweight structure. These cushions are filled with low-pressure air, providing thermal insulation and structural stability against wind or snow loads. If needed, small cables can be used for additional tensioning and support. Under typical loading conditions, ETFE cushions can range from 5 to 15 feet wide and reach up to 200 feet in length.

EFTE is printable, it has self-cleaning because of very good anti-adhesive surface properties and it is complete recyclable. Long life of more than 30 years
} 


\section{Conclusion}

In general, the public space is composed, ordered and maintained according to its use and social perception. This is what we can call "orderly public space", that is, conceived as a whole and contemplating everything that constitutes it, from ground treatment to architectural surroundings, furniture and urban furniture to urban afforestation. Piotrowska design manages to give this feeling of ordered public space

But, specially in the central city, this does not mean working with mimetic criteria or interpreting the decisions of yesteryear. On the contrary, with regard to urban furniture, solutions of contemporary design are preferable to solutions based on classic and historical forms, which, in most cases, become imitations that are out of character and out of place in time and space.

Historically, city centres have always been a setting for innovation in materials, public art, design and furniture repertoires. Technological evolution, understood as technical evolution and evolution in management criteria, made the city centre the first recipient of technical and design innovations. This is a value that we must preserve if we do not want our historic centres to look more like museums than cities, as happens today in many cities.

The "conservation" policies of historic centres have been misinterpreted on several occasions; while on the constructive level, conservation is possible thanks to the use of new materials or construction techniques, on the level of the urban landscape - including furniture, there is a tendency to freeze that landscape.

These actions do not take into account that the historic centres are living and lived areas of the city, especially in the historical dimension and that, trying to freeze the urban form at a certain point in its evolution, it goes against one of the fundamental characteristics of the centre. It is therefore not lawful to freeze the evolution of urban form in temporal points, which by definition will always be arbitrary, capable of transmitting a false image of the historic centre, unreal and out of place. For this reason, preserving the value of innovation can become a very important means of creation and management. (Remesar, A (Coord) 2005)

Piotrowska elements of urban design and public art appear old-fashioned and often kitsch. Some elements of street furniture are practically replicas of those that Davioud designed for Haussmann's Paris (Alphand, Adolphe 1867). The majority of public art reproduces figuration schemes that in many other cities were abandoned as early as the mid-1990s, but at least they retain a materiality appropriate to the public space, not like in other cities where polyester resin has replaced to bronze.

In Piotrkowsa public art, the objective was to get "works close to people": they can be touched, hugged ... but the most normal thing is that they serve tourists to take a photograph. Other elements, such as the Walk of Fame, are excessively oriented to the aspects of city promotion or urban marketing, despite the relevance that the performing and cinema arts have had and 
have in the city. The model used, Hollywood, is closer to the show than to the maintenance of remembrance and identity of the city.

In a city overflowing with dividing walls, "City of Walls", the possibilities of architectural design and the use of materials have not been sufficiently explored to achieve the proposed objectives: to improve both the living conditions of the houses and improve the visual aesthetics from the environment.

Except for honourable exceptions, the commitment to murals, "City of Murals", demonstrates an excessive attachment to the so-called "urban arts" evidencing, on the one hand, an underlying strategy centred on some topics of marginality and exclusion, and, on the other hand, the need to connect with a new "main stream" in urban decorum that is beginning to exclude the traditional performances of sculpture, replacing them with "show actions" that are part of global circuits, partly managed by the emerging industries linked to the "urban arts", supported by public budgets and determined by a "good spirit", quite uncritical.

This strategy does not really seem a long-term urban strategic option, unless we understand the role of public art from a purely temporary and, to a large extent, not really urban perspective. That aestheticization programs included urban regeneration and local development strategies are convenient. It is not so much that when management of these strategies is decanting the realization of works of art at the mercy of those who finance them, turning public art into corporate art, that is, marketing and advertising... or simply as part of the promotion of artists who move in a global network and for whom the intervention on the physical city represents an increase in their portfolio in the networks of Internet's private space.
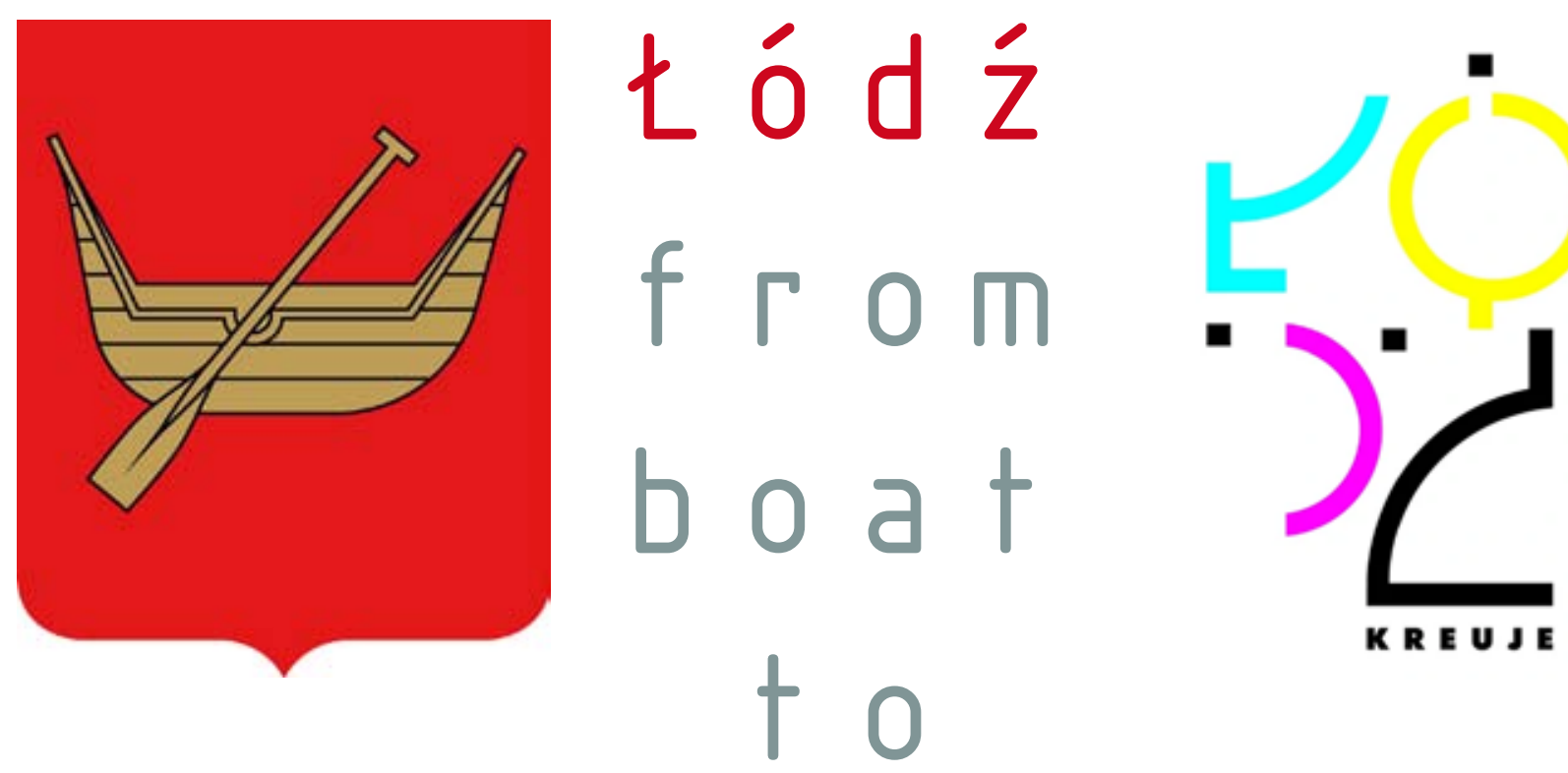


\section{References}

ALPHAND, Adolphe. 1867. 1867-1873 Les promenades de Paris / histoire, description des embellissements, dépenses de création et d'entretien des Bois de Boulogne et de Vincennes, Champs- Elysées, parcs, squares, boulevards, places plantées, études sur l'art des jardins et arboretum. Institut National d'Histoire de l'Art. Paris: J.Rothschild editeur. http://gallica.bnf.fr/ark:/12148/bpt6k6276852z/f4.image.r=Alphand

ARANTES, C - VAINER, C - MARICAT, E. 2002. A Cidade do Pensamento Único. Desmanchando COnsensos. Petrópolis: Editora Vozes.

BARTNIK, A, \& SUWART, A. 2015. «The Fountains of Łódź: Their Relevance to the Lives of its Inhabitants». Tourism, 2015. DOI 10.1515/tour-2015-0005.

BENSAÏD, Halim. 2016. «Mural Painting and the Spirit of Place versus Graffiti and Street Art». En In GralińskaToborek;A-Kazimierska-Jerzyk, W (ED) Aesthetic Energy of the City, 155-60. Lodz: Wydawnictwo Uniwersytetu Łódzkiego (Łódź University Press). https://wydawnictwo.uni.lodz.pl/produkt/aesthetic-energy-of-the-city/.

BOHIGAS, Oriol. 1985. Reconstrucció de Barcelona. Llibres a l’Abast. Barcelona: Edicions 62.

BORJA, Jordi. 1988. Estado y Ciudad. Descentralización Política y Participación. Barcelona: PPU. Promociones y Publicaciones Universitarias.

BORJA, Jordi (ed). 1995. Barcelona: un modelo de transformación urbana. Quito: Progr ama de gestión Urbana (PGU-LAC),

CAPEL, Horacio. 2005. El Modelo Barcelona: un exámen crítico. Barcelona: Ediciones del Serbal.

CIESIÓŁKA, PRZEMYSŁAW. 2017. «Rewitalizacja w polityce rozwoju kraju». Rozwój Regionalny i Polityka Regionalna, 2017.

CYSEK-PAWLAK, Monika. 2016a. "International Expo in Lodz: an opportunity or threat for the development of the city: impact of a cultural event on the spatial structure.» En Virtual City and Territory. "Back to the Sense of the City: International Monograph Book, 1187-97. Barcelona: Centre de Política de Sòl i Valoracions. UPC. http://hdl.handle. net/2117/90603.

CYSEK-PAWLAK, Monika. 2016b. «Znaczenie rewitalizacji w kontekście nadchodzących zmian polityki miejskiej i krajowej. Analiza wybranych projektów strategicznych w Łodzi». Studia Ekonomiczne Regionu Lódzkiego, 2016.

DEPARTMENT OF THE MAYOR, Department of the Mayor. City Strategy Office, y Rady Miejskiej w Łodzi. 2012. «Integrated Development Strategy for Lodz 2020+». The City of Lodz Office. https://bip.uml.lodz.pl/files/bip/public/ miasto/dokumenty/BSM strategia ang 20131018.pdf.

EL HADDAD, Marie. 2017. «Barcelona: Small-Scale Public Spaces». Doctoral, Barcelona: Universitat de Barcelona. http://www.tdx.cat/handle/10803/455143.

EUROPEAN INVESTMENT BANK. 2015. «Lodz Urban Renewal». European Investment Bank. https://www.eib.org/ en/projects/pipelines/all/20140294.

FLEMING, M. 2012. «Legitimating Urban “Revitalisation" Strategies in Post-socialist Łódź». East European Politics and Societies, 2012. https://doi.org/10.1177/0888325411415400.

GRALINSKA-TOBOREK, Agnieszka- KAZIMIERSKA-JERZYK, Wioletta. 2014. Experiences of Art in Urban Space. Lodz.: Urban Forms. 978-83-939800-0-0.

HERNANDO, Mateo; REMESAR AGUILAR, Nemo A. 2011. «The 'Employment in the Neighbourhoods' project: A local economic development experience in Catalonia». Local Economy, 2011.

KACZMAREK, Sylwia, \& MARCINCZAK, Szymon. 2013. «The blessing in Disguise. Urban regeneration in Poland in a neo-liberal milieu». En LEARY, M.E \& MCCARTHY, J. The Routledge Companion to urban regeneration, 98-106. Milton Park, Abingdon: Routledge. Taylor \& Francis Group.

KAZIMIERCZAK, J. 2010. «Memorial plaques and monuments in Łódź-Śródmieście (the City Centre District) commemorating people and events from the history of the city». Tourism, 2010. DOI 10.2478/v10106-010-0002-0. 
KAZIMIERCZAK J. \& KOSMOWSKI P. 2017. «In the shadow of the urban regeneration megaproject: Urban transitions in downtown Łódź, Poland». Urban Development Issues, 2017. 10.2478/udi-2018-0011.

KAZIMIERSKA-JERZYK, W. 2015. «The Old Market in Lodz. A place without an axikological identity. Classic Aesthetic Qualities as a Transfiguration potential». On the W@terfront. Public Art.Urban Design.Civic Participation.Urban Regeneration, 2015. https://revistes.ub.edu/index.php/waterfront/article/view/18691.

KAZIMIERSKA-JERZYK, Wioletta. 2019. «Aesthetic and Ethical Aspects of Responsibility for Mural Galleries (Comparative Analysis of Collections in Zaspa/Gdańsk, Łódź and Dulwich/London).» On the W@terfront, 2019. https://doi.org/10.1344/waterfront2019.61.6.7.

MACHLAŃSKi, Piotr. 2010. The Piotrkowska Trail. Łódź: City of Lodz. http://przetargi.bip.uml.lodz.pl/pokaz/plik. htm?idPlik=3058.

MARCINIAK, K, \& TUROWSKI, K. 2011. Streets of Crocodiles. Photography, Media, and Postsocialist Landscapes in Poland. Chicago: Intellect.

MONCLUS, Fco. JAVIER. 2003. «El Modelo Barcelona, ¿Una fórmula Original? de la "Reconstrucción" a los Proyectos urbanos estratégicos (1997-2004)». Perspectivas Urbanas, 2003. http://www.raco.cat/index.php/Perspectivas/ article/view/84991 [Consulta: 09-01-17].

MONTANER, J.M.- ALVAREZ, F - MUXÍ, Z (ED). 2011. Archivo Crítico Modelo Barcelona, 1973-2004. Barcelona: Ajuntament de Barcelona.

RADY MIEJSKIEJ W ŁODZI. 2009. «Strategia Rozwoju Ulicy Piotrkowskiej w Łodzi». http://d.polskatimes.pl/k/r/9/ d5/77/4d7f4c0c2b9db_z.pdf.

RAJKOWSKA Joanna. 2014. «Pasaż Roży 2014, projekt publiczny». Website. Joanna Rajkowska (blog). 2014. http:// www.rajkowska.com/pasaz-rozy/.

REMESAR, A (Coord). 2005. Do Projecto ao Objecto. Manual de Boas Práticas de Mobiliario Urbano em Centros Históricos. Lisboa: Centro Portugês de Design.

REMESAR AGUILAR, NEMO. 2016. «Employment, Social Cohesion and Territory. Integrating labour market policies into urban regeneration processes in Catalonia: The Employment in the Neighbourhoods case study». En in REMESAR, A (ED) The Art of Urban Design in Urban Regeneration, 27-61. Barcelona: Edicions de la Universitat de Barcelona.

REMESAR, Antoni. 2011. "O carácter simbólico da rua, identidade e apropiação». En in Brandao, P (ED) A rua é nossa... de todos nós ! Lisboa: MUDE- Instituto Superior Técnico.

REMESAR, ANTONI. 2013. «Barcelona: Un modelo de Arte Público y Diseño Urbano». En in HAMANN, Johana (ED) LIMA: ESPACIO PÚBLICO, ARTE Y CIUDAD, 13-54. Lima: Pontificia Universidad Católica del Perú.

REMESAR, Antoni. 2016. «New Urban Decorum? Aesthetics To and Fro». En In GRALIŃSKA-TOBOREK;A -KAZIMIERSKA-JERZYK, W (ED) Aesthetic Energy of the City, 19-54. Lodz: Wydawnictwo Uniwersytetu Łódzkiego (Łódź University Press). https://wydawnictwo.uni.lodz.pl/produkt/aesthetic-energy-of-the-city/.

\section{Acknowledgments}

This work has been possible with the support of the projects HAR2012-30874 and HAR2017-88672-R financed by the Ministry of Science and Innovation of Spain. 